4

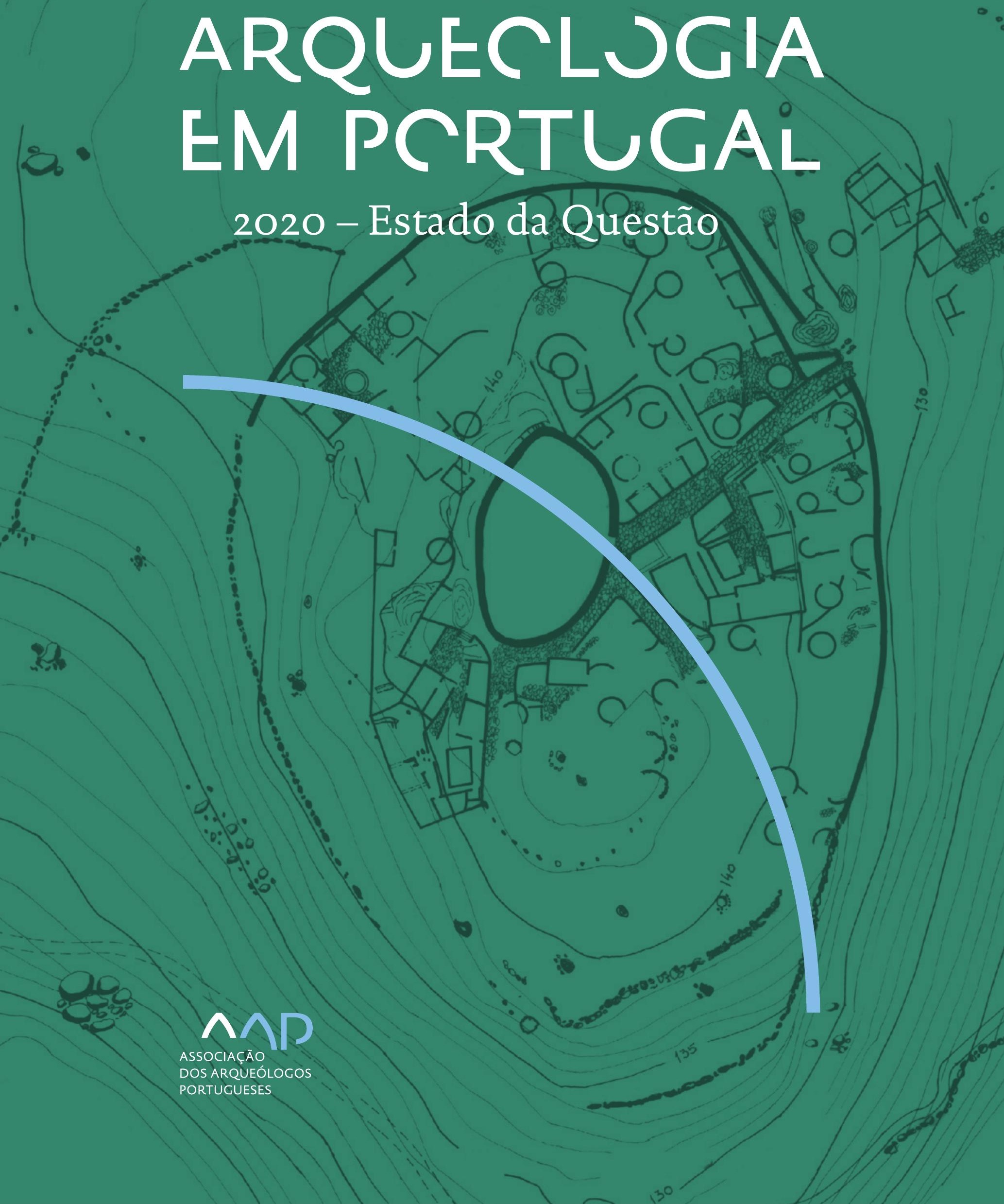


Coordenação editorial: José Morais Arnaud, César Neves e Andrea Martins Design gráfico: Flatland Design

AAP - ISBN: 978-972-9451-89-8

CITCEM - ISBN: 978-989-8970-25-1

Associação dos Arqueólogos Portugueses e CITCEM

Lisboa, 2020

O conteúdo dos artigos é da inteira responsabilidade dos autores. Sendo assim a Associação dos Arqueólogos Portugueses declina qualquer responsabilidade por eventuais equívocos ou questões de ordem ética e legal.

Desenho de capa:

Planta do castro de Monte Mozinho (Museu Municipal de Penafiel).

\section{$\hat{\wedge} \mathrm{P}$}

DOS ARQUEÓLOGOS PORTUGUESES

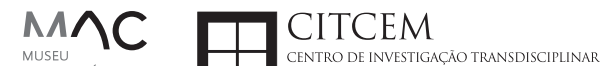
MUSEU
ARQUELLÓGICO
DO CARMO
U.PORTO

FLUP FACULDADE DE LETRAS
UNIVERSIDADE DO PORTO

Apoio

EC para a Ciência 


\section{Índice}

15 Prefácio

José Morais Arnaud

\section{Historiografia e Teoria}

17 Território, comunidade, memória e emoção: a contribuição da história da arqueologia (algumas primeiras e breves reflexões)

Ana Cristina Martins

25 Como descolonizar a arqueologia portuguesa?

Rui Gomes Coelho

41 Arqueologia e Modernidade: uma revisitação pessoal e breve de alguns aspetos da obra homónima de Julian Thomas de 2004

Vítor Oliveira Jorge

57 Dados para a História das Mulheres na Arqueologia portuguesa, dos finais do século XIX aos inícios do século XX: números, nomes e tabelas

Filipa Dimas / Mariana Diniz

73 Retractos da arqueologia portuguesa na imprensa: (in)visibilidades no feminino

Catarina Costeira / Elsa Luís

85 Arqueologia e Arqueólogos no Norte de Portugal Jacinta Bugalhão

101 Vieira Guimarães (1864-1939) e a arqueologia em Tomar: uma abordagem sobre o território e as gentes

João Amendoeira Peixoto / Ana Cristina Martins

115 Os memoráveis? A arqueologia algarvia na imprensa nacional e regional na presente centúria (2001-2019): características, visões do(s) passado(s) e a arqueologia

enquanto marca

Frederico Agosto / João Silva

129 A Evolução da Arqueologia Urbana e a Valorização Patrimonial no Barlavento Algarvio: Os casos de Portimão e Silves

Artur Mateus / Diogo Varandas / Rafael Boavida

\section{Gestão, Valorização e Salvaguarda do Património}

145 O Caderno Reivindicativo e as condições de trabalho em Arqueologia Miguel Rocha / Liliana Matias Carvalho / Regis Barbosa / Mauro Correia / Sara Simões / Jacinta Bugalhão / Sara Brito / Liliana Veríssimo Carvalho / Richard Peace / Pedro Peça / Cézer Santos

155 Os Estudos de Impacte Patrimonial como elemento para uma estratégia sustentável de minimização de impactes no âmbito de reconversões agrícolas Tiago do Pereiro

165 Salvaguarda de Património arqueológico em operações florestais: gestão e sensibilização Filipa Bragança / Gertrudes Zambujo / Sandra Lourenço / Belém Paiva / Carlos Banha / Frederico Tatá Regala / Helena Moura / Jacinta Bugalhão / João Marques / José Correia / Pedro Faria / Samuel Melro

179 Os valores do Património: uma investigação sobre os Sítios Pré-históricos de Arte Rupestre do Vale do Rio Côa e de Siega Verde José Paulo Francisco 
189 Conjugando recursos arqueológicos e naturais para potenciar as visitas ao Geoparque Litoral de Viana do Castelo (Noroeste de Portugal)

Hugo A. Sampaio / Ana M.S. Bettencourt / Susana Marinho / Ricardo Carvalhido

203 Áreas de Potencial Arqueológico na Região do Médio Tejo: Modelo Espacial Preditivo Rita Ferreira Anastácio / Ana Filipa Martins / Luiz Oosterbeek

223 Património Arqueológico e Gestão Territorial: O contributo da Arqueologia para a revisão do PDM de Avis

Ana Cristina Ribeiro

237 A coleção arqueológica do extinto Museu Municipal do Porto - Origens, Percursos e Estudos

Sónia Couto

251 Valpaços - uma nova carta arqueológica

Pedro Pereira / Maria de Fátima Casares Machado

263 Arqueologia na Cidade de Peniche

Adriano Constantino / Luís Rendeiro

273 Arqueologia Urbana: a cidade de Lagos como caso de Estudo Cátia Neto

285 Estratégias de promoção do património cultural subaquático nos Açores. O caso da ilha do Faial

José Luís Neto / José Bettencourt / Luís Borges / Pedro Parreira

297 Carta Arqueológica da Cidade Velha: Uma primeira abordagem

Jaylson Monteiro / Nireide Tavares / Sara da Veiga / Claudino Ramos / Edson Brito /

Carlos Carvalho / Francisco Moreira / Adalberto Tavares

311 Antropologia Virtual: novas metodologias para a análise morfológica e funcional Ricardo Miguel Godinho / Célia Gonçalves

\section{Didáctica da Arqueologia}

327 Como os projetos de Arqueologia podem contribuir para uma comunidade culturalmente mais consciente Alexandra Figueiredo / Claúdio Monteiro / Adolfo Silveira / Ricardo Lopes

337 Educação Patrimonial - Um cidadão esclarecido é um cidadão ativo! Ana Paula Almeida

351 A aproximação da Arqueologia à sala de aula: um caso de estudo no $3^{\circ}$ ciclo do Ensino Básico Luís Serrão Gil

363 Arqueologia 3.o - Pensar e comunicar a Arqueologia para um futuro sustentável Mónica Rolo

377 “Conversa de Arqueólogos" - Divulgar a Arqueologia em tempos de Pandemia Diogo Teixeira Dias

389 Escola Profissional de Arqueologia: desafios e oportunidades Susana Nunes / Dulcineia Pinto / Júlia Silva / Ana Mascarenhas

399 Os Museus de Arqueologia e os Jovens: a oferta educativa para o público adolescente Beatriz Correia Barata / Leonor Medeiros

411 O museu universitário como mediador entre a ciência e a sociedade: o exemplo da secção de arqueologia no Museu de História Natural e da Ciência da Universidade do Porto (MHNC-UP)

Rita Gaspar 
421 Museu de Lanifícios: Real Fábrica de Panos. Atividades no âmbito da Arqueologia Beatriz Correia Barata / Rita Salvado

427 Arqueologia Pública e o caso da localidade da Mata (Torres Novas) Cláudia Manso / Ana Rita Ferreira / Cristiana Ferreira / Vanessa Cardoso Antunes

431 Do sítio arqueológico ao museu: um percurso (também) didático Lídia Fernandes

447 Estão todos convidados para a Festa! E para dançar também... O projecto do Serviço Educativo do Museu Arqueológico do Carmo na $5^{\underline{a}}$ Edição da Festa da Arqueologia Rita Pires dos Santos

459 O “Clã de Carenque”, um projeto didático de arqueologia Eduardo Gonzalez Rocha

469 Mediação cultural: peixe que puxa carroça nas Ruínas Romanas de Troia Inês Vaz Pinto / Ana Patrícia Magalhães / Patrícia Brum / Filipa Santos

481 Didática Arqueológica, experiências do Projeto Mértola Vila Museu Maria de Fátima Palma / Clara Rodrigues / Susana Gómez / Lígia Rafael

\section{Arte Rupestre}

497 Os inventários de arte rupestre em Portugal Mila Simões de Abreu

513 O projeto FIRST-ART - conservação, documentação e gestão das primeiras manifestações de arte rupestre no Sudoeste da Península Ibérica: as grutas do Escoural e Maltravieso Sara Garcês / Hipólito Collado / José Julio García Arranz / Luiz Oosterbeek / António Carlos Silva / Pierluigi Rosina / Hugo Gomes / Anabela Borralheiro Pereira / George Nash / Esmeralda Gomes / Nelson Almeida / Carlos Carpetudo

523 Trabalhos de documentação de arte paleolítica realizados no âmbito do projeto PalæoCôa André Tomás Santos / António Fernando Barbosa / Luís Luís / Marcelo Silvestre / Thierry Aubry

537 Imagens fantasmagóricas, silhuetas elusivas: as figuras humanas na arte do Paleolítico Superior da região do Côa Mário Reis

$55^{1}$ Os motivos zoomórficos representados nas placas de tear de Vila Nova de São Pedro (Azambuja, Portugal) Andrea Martins / César Neves / José M. Arnaud / Mariana Diniz

571 Arte Rupestre do Monte de Góios (Lanhelas, Caminha). Síntese dos resultados dos trabalhos efectuados em 2007-2009 Mário Varela Gomes

599 Gravuras rupestres de barquiformes no Monte de S. Romão, Guimarães, Noroeste de Portugal Daniela Cardoso

613 Círculos segmentados gravados na Bacia do Rio Lima (Noroeste de Portugal): contributos para o seu estudo Diogo Marinho / Ana M.S. Bettencourt / Hugo Aluai Sampaio

631 Equídeos gravados no curso inferior do Rio Mouro, Monção (NW Portugal). Análise preliminar Coutinho, L.M. / Bettencourt, A.M.S / Sampaio, Hugo A.S

645 Paletas na Arte Rupestre do Noroeste de Portugal. Inventário preliminar Bruna Sousa Afonso / Ana M. S. Bettencourt / Hugo A. Sampaio 


\section{Pré-História}

661 O projeto Miño/Minho: balanço de quatro anos de trabalhos arqueológicos Sérgio Monteiro-Rodrigues / João Pedro Cunha-Ribeiro / Eduardo Méndez-Quintas / Carlos Ferreira / Pedro Xavier / José Meireles / Alberto Gomes / Manuel Santonja / Alfredo Pérez-González

677 A ocupação paleolítica da margem esquerda do Baixo Minho: a indústria lítica do sítio de Pedreiras 2 (Monção, Portugal) e a sua integração no contexto regional Carlos Ferreira / João Pedro Cunha-Ribeiro / Sérgio Monteiro-Rodrigues / Eduardo Méndez-Quintas / Pedro Xavier / José Meireles / Alberto Gomes / Manuel Santonja / Alfredo Pérez-González

693 O sítio acheulense do Plistocénico médio da Gruta da Aroeira Joan Daura / Montserrat Sanz / Filipa Rodrigues / Pedro Souto / João Zilhão

703 As sociedades neandertais no Barlavento algarvio: modelos preditivos com recurso aos SIG

Daniela Maio

715 A utilização de quartzo durante o Paleolítico Superior no território dos vales dos rios Vouga e Côa

Cristina Gameiro / Thierry Aubry / Bárbara Costa / Sérgio Gomes / Luís Luís / Carmen Manzano / André Tomás Santos

733 Uma perspetiva diacrónica da ocupação do concheiro do Cabeço da Amoreira (Muge, Portugal) a partir da tecnologia lítica Joana Belmiro / João Cascalheira / Célia Gonçalves

745 Novos dados sobre a Pré-história Antiga no concelho de Palmela. A intervenção arqueológica no sítio do Poceirão I

Michelle Teixeira Santos

757 Problemas em torno de Datas Absolutas Pré-Históricas no Norte do Alentejo Jorge de Oliveira

771 Povoamento pré-histórico nas áreas montanhosas do NO de Portugal: o Abrigo 1 de Vale de Cerdeira Pedro Xavier / José Meireles / Carlos Alves

783 Apreciação do povoamento do Neolítico Inicial na Baixa Bacia do Douro. A Lavra I (Serra da Aboboreira) como caso de estudo Maria de Jesus Sanches

797 O Processo de Neolitização na Plataforma do Mondego: os dados do Sector C do Outeiro dos Castelos de Beijós (Carregal do Sal)

João Carlos de Senna-Martinez / José Manuel Quintã Ventura / Andreia Carvalho / Cíntia Maurício

823 Novos trabalhos na Lapa da Bugalheira (Almonda, Torres Novas) Filipa Rodrigues / Pedro Souto / Artur Ferreira / Alexandre Varanda / Luís Gomes / Helena Gomes / João Zilhão

837 A pedra polida e afeiçoada do sítio do Neolítico médio da Moita do Ourives (Benavente, Portugal)

César Neves

857 Casal do Outeiro (Encarnação, Mafra): novos contributos para o conhecimento do povoamento do Neolítico final na Península de Lisboa.

Cátia Delicado / Carlos Maneira e Costa / Marta Miranda / Ana Catarina Sousa

873 Stresse infantil, morbilidade e mortalidade no sítio arqueológico do Neolítico Final/ Calcolítico ( $4^{\circ}$ e $3^{\circ}$ milénio a.C.) do Monte do Carrascal 2 (Ferreira do Alentejo, Beja) Liliana Matias de Carvalho / Sofia N. Wasterlain 
885 Come together: O Conjunto Megalítico das Motas (Monção, Viana do Castelo) e as expressões Campaniformes do Alto Minho Ana Catarina Basílio / Rui Ramos

899 Trabalhos arqueológicos no sítio Calcolítico da Pedreira do Poio Carla Magalhães / João Muralha / Mário Reis / António Batarda Fernandes

913 O sítio arqueológico de Castanheiro do Vento. Da arquitectura do sítio à arquitectura de um território João Muralha Cardoso

925 Estudo zooarqueológico das faunas do Calcolítico final de Vila Nova de São Pedro (Azambuja, Portugal): Campanhas de 2017 e 2018 Cleia Detry / Ana Catarina Francisco / Mariana Diniz / Andrea Martins / César Neves / José Morais Arnaud

943 As faunas depositadas no Museu Arqueológico do Carmo provenientes de Vila Nova de São Pedro (Azambuja): as campanhas de 1937 a 1967 Ana Catarina Francisco / Cleia Detry / César Neves / Andrea Martins / Mariana Diniz / José Morais Arnaud

959 Análise funcional de material lítico em sílex do castro de Vila Nova de S. Pedro (Azambuja, Portugal): uma primeira abordagem Rafael Lima

971 O recinto da Folha do Ouro 1 (Serpa) no contexto dos recintos de fossos calcolíticos alentejanos

António Carlos Valera / Tiago do Pereiro / Pedro Valério / António M. Monge Soares

\section{Proto-História}

987 Produção de sal marinho na Idade do Bronze do noroeste Português. Alguns dados para uma reflexão

Ana M. S. Bettencourt / Sara Luz / Nuno Oliveira / Pedro P. Simões / Maria Isabel C. Alves / Emílio Abad-Vidal

1001 A estátua-menir do Pedrão ou de São Bartolomeu do Mar (Esposende, noroeste de Portugal) no contexto arqueológico da fachada costeira de entre os rios Neiva e Cávado Ana M. S. Bettencourt / Manuel Santos-Estévez / Pedro Pimenta Simões / Luís Gonçalves

1015 O Castro do Muro (Vandoma/Baltar, Paredes) - notas para uma biografia de ocupação da Idade do Bronze à Idade Média

Maria Antónia D. Silva / Ana M. S. Bettencourt / António Manuel S. P. Silva / Natália Félix

1031 Do Bronze Final à Idade Média - continuidades e hiatos na ocupação de Povoados em Oliveira de Azeméis João Tiago Tavares / Adriaan de Man

1041 As faunas do final da Idade do Bronze no Sul de Portugal: leituras desde o Outeiro do Circo (Beja)

Nelson J. Almeida / Íris Dias / Cleia Detry / Eduardo Porfírio / Miguel Serra

1055 A Espada do Monte das Oliveiras (Serpa) - uma arma do Bronze Pleno do Sudoeste Rui M. G. Monge Soares / Pedro Valério / Mariana Nabais / António M. Monge Soares

1065 São Julião da Branca (Albergaria-a-Velha) - Investigação e valorização de um povoado do Bronze Final

António Manuel S. P. Silva / Paulo A. P. Lemos / Sara Almeida e Silva / Edite Martins de Sá

1083 Do castro de S. João ao Mosteiro de Santa Clara: notícia de uma intervenção arqueológica, em Vila do Conde Rui Pinheiro 
1095 O castro de Ovil (Espinho), um quarto de século de investigação - resultados e questões em aberto

Jorge Fernando Salvador / António Manuel S. P. Silva

1111 O Castro de Salreu (Estarreja), um povoado proto-histórico no litoral do Entre Douro e Vouga

Sara Almeida e Silva / António Manuel S. P. Silva / Paulo A. P. Lemos / Edite Martins de Sá

1127 Castro de Nossa Senhora das Necessidades (Sernancelhe): uma primeira análise artefactual Telma Susana O. Ribeiro

${ }_{1141}$ A cividade de Bagunte. O estado atual da investigação Pedro Brochado de Almeida

1153 Zoomorfos na cerâmica da Idade do Ferro no NW Peninsular: inventário, cronologias e significado Nuno Oliveira / Cristina Seoane

1163 Vasos gregos em Portugal: diferentes maneiras de contar a história do intercâmbio cultural na Idade do Ferro

Daniela Ferreira

1175 Os exotica da necrópole da Idade do Ferro do Olival do Senhor dos Mártires (Alcácer do Sal) no seu contexto regional

Francisco B. Gomes

\section{Antiguidade Clássica e Tardia}

1191 O uso de madeira como combustível no sítio da Quinta de Crestelos (Baixo Sabor): da Idade do Ferro à Romanização Filipe Vaz / João Tereso / Sérgio Simões Pereira / José Sastre / Javier Larrazabal Galarza / Susana Cosme / José António Pereira / Israel Espi

1207 Cultivos de Época Romana no Baixo Sabor: continuidade em tempos de mudança? João Pedro Tereso / Sérgio Simões Pereira / Filipe Santos / Luís Seabra / Filipe Vaz

1221 A casa romana na Hispânia: aplicação dos modelos itálicos nas províncias ibéricas Fernanda Magalhães / Diego Machado / Manuela Martins

1235 As pinturas murais romanas da Rua General Sousa Machado, n. ${ }^{5}$ 1, Chaves José Carvalho

1243 Trás do Castelo (Vale de Mir, Pegarinhos, Alijó) - Uma exploração agrícola romana do Douro

Tony Silvino / Pedro Pereira

1255 A sequência de ocupação no quadrante sudeste de Bracara Augusta: as transformações de uma unidade doméstica Lara Fernandes / Manuela Martins

1263 Os Mosaicos com decoração geométrica e geométrico-vegetalista dos sítios arqueológicos da área do Conuentus Bracaraugustanus. Novas abordagens quanto à conservação, restauro, decoração e datação Maria de Fátima Abraços / Licínia Wrench

1277 “Casa Romana” do Castro de São Domingos (Cristelos, Lousada): Escavação, Estudo e Musealização Paulo André de P. Lemos

1291 A arqueobotânica no Castro de Guifões (Matosinhos, Noroeste de Portugal): O primeiro estudo carpológico

Luís Seabra / Andreia Arezes / Catarina Magalhães / José Varela / João Pedro Tereso 
1305 Um Horreum Augustano na Foz do Douro (Monte do Castelo de Gaia, Vila Nova de Gaia) Rui Ramos

1311 Ponderais romanos na Lusitânia: padrões, formas, materiais e contextos de utilização Diego Barrios Rodríguez

1323 Um almofariz centro-itálico na foz do Mondego

Marco Penajoia

1335 Estruturas romanas de Carnide - Lisboa Luísa Batalha / Mário Monteiro / Guilherme Cardoso

1347 O contexto funerário do sector da "necrópole NO" da Rua das Portas de S. Antão (Lisboa): o espaço, os artefactos, os indivíduos e a sua interconectividade na interpretação do passado Sílvia Loja, José Carlos Quaresma, Nelson Cabaço, Marina Lourenço, Sílvia Casimiro, Rodrigo Banha da Silva, Francisca Alves-Cardoso

${ }_{1361}$ Povoamento em época Romana na Amadora - resultados de um projeto pluridisciplinar Gisela Encarnação / Vanessa Dias

1371 A Arquitectura Residencial em Mirobriga (Santiago do Cacém): contributo a partir de um estudo de caso Filipe Sousa / Catarina Felício

${ }_{1385}$ O fim do ciclo. Saneamento e gestão de resíduos nos edifícios termais de Mirobriga (Santiago do Cacém)

Catarina Felício / Filipe Sousa

1399 Balsa, Topografia e Urbanismo de uma Cidade Portuária Vítor Silva Dias / João Pedro Bernardes / Celso Candeias / Cristina Tété Garcia

1413 No Largo das Mouras Velhas em Faro (2017): novas evidências da necrópole norte de Ossonoba e da sua ocupação medieval Ricardo Costeira da Silva / Paulo Botelho / Fernando Santos / Liliana Nunes

1429 Instrumentos de pesca recuperados numa fábrica de salga em Ossonoba (Faro) Inês Rasteiro / Ricardo Costeira da Silva / Paulo Botelho

1439 A Necrópole Romana do Eirô, Duas Igrejas (Penafiel): intervenção arqueológica de 2016 Laura Sousa / Teresa Soeiro

1457 Ritual, descarte ou afetividade? A presença de Canis lupus familiaris na Necrópole Noroeste de Olisipo (Lisboa)

Beatriz Calapez Santos / Sofia Simões Pereira / Rodrigo Banha da Silva / Sílvia Casimiro / Cleia Detry / Francisca Alves Cardoso

1467 Dinâmicas económicas em Bracara na Antiguidade Tardia Diego Machado / Manuela Martins / Fernanda Magalhães / Natália Botica

1479 Cerâmicas e Vidros da Antiguidade Tardia do Edifício sob a Igreja do Bom Jesus (Vila Nova de Gaia) Joaquim Filipe Ramos

1493 Novos contributos para a topografia histórica de Mértola no período romano e na Antiguidade Tardia Virgílio Lopes

\section{8. Época Medieval}

1511 Cerâmicas islâmicas no Garb setentrional "português": algumas evidências e incógnitas Constança dos Santos / Helena Catarino / Susana Gómez / Maria José Gonçalves / Isabel Inácio / Gonçalo Lopes / Jacinta Bugalhão / Sandra Cavaco / Jaquelina Covaneiro / Isabel Cristina Fernandes / Ana Sofia Gomes 
1525 Contributo para o conhecimento da cosmética islâmica, em Silves, durante a Idade Média Rosa Varela Gomes

1537 Yábura e o seu território - uma análise histórico-arqueológica de Évora entre os séculos VIII-XII José Rui Santos

1547 A encosta sul do Castelo de Palmela - resultados preliminares da escavação arqueológica Luís Filipe Pereira / Michelle Teixeira Santos

1559 A igreja de São Lourenço (Mouraria, Lisboa): um conjunto de silos e de cerâmica medieval islâmica

Andreia Filipa Moreira Rodrigues

1571 O registo material de movimentações populacionais no Médio Tejo, durante os séculos XII-XIII. Dois casos de "sunken featured buildings", nos concelhos de Cartaxo e Torres Novas Marco Liberato / Helena Santos / Nuno Santos

1585 O nordeste transmontano nos alvores da Idade média. Notas para reflexão Ana Maria da Costa Oliveira

1601 Sepulturas escavadas na rocha do Norte de Portugal e do Vale do Douro: primeiros resultados do Projecto SER-NPVD

Mário Jorge Barroca / César Guedes / Andreia Arezes / Ana Maria Oliveira

1619 "Portucalem Castrum Novum" entre o Mediterrâneo e o Atlântico: o estudo dos materiais cerâmicos alto-medievais do arqueossítio da rua de D. Hugo, nํ. 5 (Porto) João Luís Veloso

1627 A Alta Idade Média na fronteira de Lafões: notas preliminares sobre a Arqueologia no Concelho de Vouzela

Manuel Luís Real / Catarina Tente

1641 Um conjunto cerâmico medieval fora de portas: um breve testemunho aveirense Susana Temudo

${ }_{1651}$ Os Lóios do Porto: uma perspetiva integrada no panorama funerário da Baixa Idade Média à Época Moderna em meios urbanos em Portugal

Ana Lema Seabra

1659 O Caminho Português Interior de Santiago como eixo viário na Idade Média Pedro Azevedo

1665 Morfologia Urbana: Um exercício em torno do Castelo de Ourém André Donas-Botto / Jaqueline Pereira

1677 Intervenção arqueológica na Rua Marquês de Pombal/Largo do Espírito Santo (Bucelas, Loures)

Florbela Estêvão / Nathalie Antunes-Ferreira / Dário Ramos Neves / Inês Lisboa

1691 O Cemitério Medieval do Poço do Borratém e a espacialidade funerária na cidade de Lisboa Inês Belém / Vanessa Filipe / Vasco Noronha Vieira / Sónia Ferro / Rodrigo Banha da Silva

1705 Um Espaço Funerário Conventual do séc. XV em Lisboa: o caso do Convento de São Domingos da Cidade Sérgio Pedroso / Sílvia Casimiro / Rodrigo Banha da Silva / Francisca Alves Cardoso

\section{9. Época Moderna e Contemporânea}

1721 Arqueologia Moderna em Portugal: algumas reflexões críticas em torno da quantificação de conjuntos cerâmicos e suas inferências históricas e antropológicas Rodrigo Banha da Silva / André Bargão / Sara da Cruz Ferreira

1733 Faianças de dois contextos entre os finais do século XVI e XVIII do Palácio dos Condes de Penafiel, Lisboa

Martim Lopes / Tomás Mesquita 
1747 Um perfil de consumo do século XVIII na foz do Tejo: O caso do Mercado da Ribeira, Lisboa Sara da Cruz Ferreira / Rodrigo Banha da Silva / André Bargão

1761 Os Cachimbos dos Séculos XVII e XVIII do Palácio Mesquitela e Convento dos Inglesinhos (Lisboa)

Inês Simão / Marina Pinto / João Pimenta / Sara da Cruz Ferreira / André Bargão / Rodrigo Banha da Silva

1775 "Tomar os fumos da erua que chamão em Portugal erua sancta». Estudo de Cachimbos provenientes da Rua do Terreiro do Trigo, Lisboa

Miguel Martins de Sousa / José Pedro Henriques / Vanessa Galiza Filipe

1787 Cachimbos de Barro Caulínitico da Sé da Cidade Velha (República de Cabo Verde)

Rodrigo Banha da Silva / João Pimenta / Clementino Amaro

1801 Algumas considerações sobre espólio não cerâmico recuperado no Largo de Jesus (Lisboa) Carlos Boavida

1815 Adereços de vidro, dos séculos XVI-XVIII, procedentes do antigo Convento de Santana de Lisboa (anéis, braceletes e contas)

Joana Gonçalves / Rosa Varela Gomes / Mário Varela Gomes

1837 Da ostentação, luxo e poder à simplicidade do uso quotidiano: arqueologia e simbologia de joias e adornos da Idade Moderna Portuguesa Jéssica Iglésias

1849 Os amuletos em Portugal - dos objetos às superstições: o coral vermelho Alexandra Vieira

1865 Cerâmicas de Vila Franca de Xira nos séculos XV e XVI Eva Pires

1879 «Não passa por teu o que me pertence». Marcas de individualização associadas a faianças do Convento de Nossa Senhora de Aracoeli, Alcácer do Sal Catarina Parreira / Íris Fragoso / Miguel Martins de Sousa

1891 Cerâmica de Leiria: alguns focos de produção

Jaqueline Pereira / André Donas-Botto

1901 Os Fornos na Rua da Biquinha, em Óbidos Hugo Silva / Filipe Oliveira

1909 A casa de Pêro Fernandes, contador dos contos de D. Manuel I: o sítio arqueológico da Silha do Alferes, Seixal (século XVI) Mariana Nunes Ferreira

1921 O Alto da Vigia (Sintra) e a vigilância e defesa da costa Alexandre Gonçalves / Sandra Santos

1937 O contexto da torre sineira da Igreja de Santa Maria de Loures Paulo Calaveira / Martim Lopes

1949 A Necrópole do Hospital Militar do Castelo de São Jorge e as práticas funerárias na Lisboa de Época Moderna Susana Henriques / Liliana Matias de Carvalho / Ana Amarante / Sofia N. Wasterlain

1963 SAND - Sarilhos Grandes Entre dois Mundos: o adro da Igreja e a Paleobiologia dos ossos humanos recuperados

Paula Alves Pereira / Roger Lee Jesus / Bruno M. Magalhães

1975 Expansão urbana da vila de Cascais no século XVII e XVIII: a intervenção arqueológica na Rua da Vitória no 15 a 17

Tiago Pereira / Vanessa Filipe

1987 Novos dados para o conhecimento do Urbanismo de Faro em época Moderna Ana Rosa 
1995 Um exemplo de Arqueologia Urbana em Alcoutim: o Antigo Edifício dos CTT Marco Fernandes / Marta Dias / Alexandra Gradim / Virgílio Lopes / Susana Gómez Martínez

2007 Palácio dos Ferrazes (Rua das Flores/Rua da Vitória, Porto): a cocheira de Domingos Oliveira Maia

Francisco Raimundo

2021 As muitas vidas de um edifício urbano: História, Arqueologia e Antropologia no antigo Recreatório Paroquial de Penafiel Helena Bernardo / Jorge Sampaio / Marta Borges

2035 O convento de Nossa Senhora da Esperança de Ponta Delgada: o contributo da arqueologia para o conhecimento de um monumento identitário João Gonçalves Araújo / N’Zinga Oliveira

2047 Arqueologia na ilha do Corvo... em busca da capela de Nossa Senhora do Rosário Tânia Manuel Casimiro / José Luís Neto / Luís Borges / Pedro Parreira

2059 Perdidos à vista da Costa. Trabalhos arqueológicos subaquáticos na Barra do Tejo Jorge Freire / José Bettencourt / Augusto Salgado

2071 Arqueologia marítima em Cabo Verde: enquadramento e primeiros resultados do projecto CONCHA

José Bettencourt / Adilson Dias / Carlos Lima / Christelle Chouzenoux / Cristóvão Fonseca / Dúnia Pereira / Gonçalo Lopes / Inês Coelho / Jaylson Monteiro / José Lima / Maria Eugénia Alves / Patrícia Carvalho / Tiago Silva

2085 Trabalhos arqueológicos na Cidade Velha (Ribeira Grande de Santiago, Cabo Verde): reflexões sobre um projecto de investigação e divulgação patrimonial André Teixeira / Jaylson Monteiro / Mariana Mateus / Nireide Tavares / Cristovão Fonseca / Gonçalo C. Lopes / Joana Bento Torres / Dúnia Pereira / André Bargão / Aurélie Mayer / Bruno Zélie / Carlos Lima / Christelle Chouzenoux / Inês Henriques / Inês Pinto Coelho / José Lima / Patrícia Carvalho / Tiago Silva

2103 A antiga fortificação de Quelba / Khor Kalba (E.A.U.). Resultados de quatro campanhas de escavações, problemáticas e perspectivas futuras Rui Carita / Rosa Varela Gomes / Mário Varela Gomes / Kamyar Kamyad

2123 Colónias para homens novos: arqueologia da colonização agrária fascista no noroeste ibérico Xurxo Ayán Vila / José Mạ . Señorán Martín 


\title{
EQUÍDEOS GRAVADOS NO CURSO INFERIOR DO RIO MOURO, MONÇÃO (NW PORTUGAL). ANÁLISE PRELIMINAR
}

\author{
L. M. Coutinho' ${ }^{1}$, Ana M.S. Bettencourt ${ }^{2}$, Hugo A.S. Sampaio ${ }^{2,3}$
}

\begin{abstract}
RESUMO
Este estudo, centra-se na representação de equídeos gravados na bacia do rio Mouro, afluente da margem sul do rio Minho. Tem como objetivos o estudo da sua distribuição no espaço em relação a características físicas; a especificidade de tipos de equídeos gravados; as características dos afloramentos gravados por grupo de equídeos; e as orientações dos equídeos por tipo e a sua disposição no afloramento face a outros motivos gravados. Palavras-chave: Arte Pós-paleolítica, Tipos de equídeos, Bacia do rio Mouro.
\end{abstract}

\begin{abstract}
This paper focuses on the representation of horses graved on rocks in the Mouro River basin (NW Portugal), an afluent in the south margin of the Minho River. The objectives are the study of its distribution in space, in relation to physical characteristics; the specificity of types of graved horses; the characteristics of the rocks graved by group of horses; the orientation of horses by type and their disposition in the rock compared to other graved motifs.
\end{abstract}

Keywords: Post Paleolithic Art, River Mouro Basin.

\section{INTRODUÇÃO}

O que torna especial um lugar gravado com arte rupestre? Será a gravura em si que o dota de propriedades ou o afloramento e o local foram gravados por já serem especiais ou terem visibilidade para locais significantes? Não se pode ignorar que, para as sociedades tradicionais, alguns afloramentos e lugares contêm um significado espiritual (Bradley, 20oo; Tilley, 2002) que podem estar na origem de lendas, mitos e crenças relacionadas com seres ou propriedades que habitam dentro ou entre as rochas ou em determinados montes. Tal é o caso de muitos locais do Norte de Portugal (Bettencourt et alii, 2017b: 139; Sampaio et alii, 2018: 150). Bradley (2000) afirma que, serão os motivos, enquanto signos, que conferem uma ligação entre os lugares (enquanto espaço frequentado por populações) e os poderes sobrenaturais que os povoam. Deste modo, parte-se do princípio que, através do estudo da arte rupestre de ar livre, a Arqueologia poderá interpretar memórias do passado, partindo da premissa de que a mensagem inerente à gramática imortalizada nos afloramentos resulta de um pensamento simbólico e reflete a visão cosmogónica que as comunidades que as gravaram tinham do mundo e da realidade que as rodeava (Sampaio et alii, 2018, p. 150).

Inserida no chamado ciclo da Arte Atlântica, no seu sentido clássico, a gravação de signos e gramáticas abstratas atribuíveis ao Neolítico, entre os finais do $5^{\circ}$ e/ou inícios do $4^{\circ}$ milénios a.C. (Alves, 2009; 2017; Santos-Estévez, 2012; Bettencourt, 2013; Cardoso e Bettencourt, 2015) vão sendo substituídos por novas linguagens "artísticas", especialmente a

\footnotetext{
1. Aluno de Mestrado em Arqueologia na Universidade do Minho; coutinho@dps.uminho.pt

2. Laboratório de Paisagens, Património e Território (Lab2PT); Departamento de História do Instituto de Ciências Sociais da Universidade do Minho, Portugal.

3. Escola de Hotelaria e Turismo do Instituto Politécnico do Cávado e do Ave (ESHT | IPCA); Centro de Investigação, Desenvolvimento e Inovação em Turismo (CITur).
} 
partir do fim do $3^{\circ}$ milénio a.C. (Bettencourt, 2017a, 2017b). Aos círculos concêntricos, covinhas e sulcos, mais ou menos meandriformes, vão sendo adicionados novos motivos e composições, complexificando o discurso e, desse modo, prolongando ou alterando a memória do local, na longa temporalidade. Estes também podem surgir ex nuovo.

Identificam-se agora representações de armas, barquiformes, círculos segmentados, paletas, podomorfos e quadrúpedes, onde se enquadram os equídeos. Trata-se de uma fase mais figurativa, o que leva a que alguns investigadores os classifiquem como um novo ciclo artístico, nomeado de forma provisória como "arte figurativa" (Bettencourt, 2019b). Outros autores defendem que se inserem em novas fases da Arte Atlântica, mais recentes do que a sua fase Clássica e inicial (Santos-Estévez, 2008, 2012; Alves, 2014, Cardoso, 2015, entre outros).

Partindo do estudo concreto dos equídeos gravados ao ar livre, numa análise desenvolvida numa escala regional, embora enfatizando a microescala do lugar, os objetivos deste texto são: 1) o estudo da sua distribuição no espaço em relação a características físicas; 2) a especificidade de tipos de equídeos gravados; 3) as características dos afloramentos gravados por grupo de equídeos; 4) a disposição dos equídeos por tipo; e 5) as suas orientações e inter-relações com outros motivos gravados, também por tipo de equídeos. Na prática, este estudo incidiu no espaço territorial constituído pelo curso inferior da bacia do rio Mouro, onde foram analisados 10 afloramentos com equídeos gravados.

\section{METODOLOGIA}

A primeira fase do estudo consistiu na definição dos objetivos e do quadro teórico interpretativo, na recolha de bibliografia, cartografia e documentação gráfica e na definição de critérios de estudo de acordo com os objetivos. Numa segunda fase foram feitas visitas aos locais para observações in situ dos sítios gravados e dos seus motivos, observações do seu contexto físico e recolha fotográfica dos afloramentos para aplicação fotogramétrica. Numa terceira fase, a de trabalho avançado de gabinete, foram gerados os levantamentos fotogramétricos com utilização dos softwares Agisoft Photoscan e 3 DF Zephyr Lite versão 4.530. Foi aplicada a técnica Morphological Residual Model (MRM), que representa as diferenças morfológicas existentes na rocha a partir de um código cromático e as diferentes profundidades dos sulcos das gravuras, gerando uma nuvem de pontos e de texturas que, com a utilização do software $L a$ bmesh e aplicando os filtros Radiance Scalling e Lit Spheres, dando o tratamento $3 \mathrm{D}$ à imagem, permite remarcar os sulcos existentes na rocha. Aumentando o contraste aplica-se uma maior e mais fácil leitura à imagem de forma a proporcionar melhores interpretações das gravuras, que por vezes se encontram bastante erodidas. Posteriormente, com recurso a ferramentas de sistemas de informação geográfica (software QGIS Desktop v. 3.10.2) foi possível identificar a distribuição espacial dos afloramentos gravados num mapa hipsométrico, de modo a compreender a sua localização e as suas inter relações espaciais.

\section{O VALE DO RIO MOURO}

Inserido na denominada região do Alto Minho, o vale do rio Mouro assume uma localização a nordeste no distrito de Viana do Castelo. Nasce na Portela do Lagarto, a uma altitude de cerca de $1200 \mathrm{~m}$, na serra da Peneda, no concelho de Melgaço, e desagua na margem esquerda do rio Minho, na localidade de Ponte de Mouro, no concelho de Monção. Forma um vale de morfologia pouco sinuosa, criando um eixo natural de circulação que se desenvolve de sul para norte, no seu curso inferior, e de este para oeste, no curso superior. Corre num vale profundo e estreito, a montante, e aberto a jusante (Fig. 1). Segundo a Carta Geológica de Portugal, folha 1-B, de 1985, à escala 1/50 ooo, o substrato rochoso desta área é composto por granito de duas micas, com grão variável entre o médio a fino. Segundo a notícia explicativa desta Carta Geológica (Ribeiro e Moreira, 1986, p. 35), a área teve mineralizações de ouro e volfrâmio (ver Figura 1).

\section{INVENTÁRIO}

Após consulta do Corpus Virtual de Arte Rupestre do Noroeste Português - CVARN (www.cvarn.org), foram identificados 6 afloramentos gravados com equídeos que pertencem à bacia do rio Mouro, localizados todos no concelho de Monção. A estes foi possível adicionar mais um, publicado na Revista de Estudos Miñoráns: Proxecto Equus: un novo paradigma nas escenas de caza da arte rupestre galega e do norte de Portugal (Martínez Soto et alii, 2017) que se designou por Buraca da Moura 5, atendendo ao 
local onde se encontrava. No decorrer dos trabalhos de campo foram identificados mais três inéditos, nas freguesias de Barbeita e de Longos Vales.

Através deste trabalho foi possível elaborar o inventário que se segue. Este obedeceu aos seguintes descritores: 1) localização administrativa e coordenadas; 2) pequeno historial; 3) contexto físico e ambiental; 4) descrição do afloramento; 5) descrição dos motivos; e 6) bibliografia. O mesmo está ordenado por ordem alfabética das freguesias.

\section{Gasgaia ${ }^{4}$}

Freguesia: Barbeita.

Localização: Latitude: 42.054472; Longitude: -8.40 8861; Altitude: $252 \mathrm{~m}$.

Historial: noticiada por Bettencourt (2014d).

Contexto físico e ambiental:

Descrição do afloramento: trata-se de um afloramento pouco destacado do solo, com superfície aplanada e uma ligeira pendente.

Descrição dos motivos: apresenta vários motivos dispersos, como composições circulares, nomeadamente um círculo concêntrico e círculos, covinhas, sulcos e um equídeo bastante esquemático (Figura 2). Bibliografia: Bettencourt, 2014d; dados inéditos.

\section{Buraca da Moura 5}

Freguesia: Barbeita

Localização:Latitude:42.066944; Longitude: -8.44 3333; Altitude: $242 \mathrm{~m}$

Historial: noticiada por Bettencourt (2014d).

Contexto físico e ambiental: situado na vertente nascente do Monte da Nossa Senhora da Assunção, encaixado entre dois outeiros. O local tem visibilidade a SSE para o vale do rio Mouro.

Este afloramento dista cerca de 2,10 m para NE da rocha da Buraca da Moura 2. Exibe uma divisão natural em dois painéis devido a um filão constituído maioritariamente por feldspato.

Descrição do afloramento: Trata-se de uma rocha de granito médio a fino com $3,70 \mathrm{~m}$ de comprimento no sentido SE-NE e 3,53m no sentido SW-NW, exibindo uma forma quase triangular e rasante ao solo com uma pendente suave no sentido SW.

Descrição dos motivos: na extremidade W-NW encontra-se um equídeo sub-naturalista com orelhas bem pronunciadas, encaminhando-se para NE,

4. Por engano está referenciado no cvarn.org como Buraca da Moura 1. como se estivesse a subir o afloramento e dirigindo-se para o monte da Senhora da Assunção. Mais perto do filão de feldspato, encontramos mais dois equídeos, um em cima do outro, dirigindo-se para $\mathrm{NW}$, como se estivessem a dirigir-se de um outeiro para o outro. Neste painel é possível ainda distinguir diversas covinhas, sendo que duas delas parecem estar quase unidas por um sulco. No segundo painel, um equídeo de maiores dimensões e de estilo sub-naturalista sugere estar associado a uma figura algo irregular, ligeiramente circular, como que se a transportasse.

Bibliografia: Martínez Soto et alii, 2017. Dados inéditos (Figura 3).

\section{Nossa Senhora da Assunção 15}

Freguesia: Barbeita

Localização: Latitude: 42.056367; Longitude: -8.40 7933; Altitude: $253 \mathrm{~m}$.

Historial: Foi dado a conhecer por Bettencourt (2014b) que o descreve de modo sumário.

Contexto físico e ambiental: situado na extremidade nascente de um pequeno e estreito patamar a sul do Monte de Nossa Senhora da Assunção, a visibilidade de quem se dirige ao local e visualiza alguns motivos (composições circulares e covinhas) é direcionada para o vale do rio Mouro.

Descrição do afloramento: trata-se de um dos maiores e mais imponentes afloramentos gravados nesta área, dispondo-se em patamares separados por declives mais ou menos acentuados. Devido à construção de um parque de estacionamento, este afloramento foi em parte destruído e encontra-se parcialmente aterrado ${ }^{5}$.

Descrição dos motivos: é composto, pelo menos, por 4 painéis: dois no topo, um na pendente nascente e outro num patamar virado a este. O painel 1 , no topo aplanado, apresenta uma composição circular complexa, entre outras mais simples e covinhas. O painel 2, no patamar inferior ao do topo, também apresenta composições circulares de gramática atlântica clássica, tal como um círculo concêntrico de três voltas com covinha central, entre outros sulcos pouco nítidos, um sulco unido por covinhas e covinhas

\footnotetext{
5. Foi parcialmente partido encontrando-se a parte fraturada nas proximidades, nomeadamente na vertente este do monte, junto com outros blocos partidos, como se fosse entulho. O afloramento encontra-se em perigo de destruição pelas obras dos parque de estacionamento.
} 
dispersas. O painel 3, mais ou menos a meio do declive existente a este do painel 2, apresenta dois quadrúpedes. Estes correspondem a dois equídeos muito esquemáticos, em posição estática. Estão orientados de SE para NE. Um deles, o de maior dimensão, localizado mais a nordeste, tem a cauda e a cabeça levantadas, enquanto o outro, de menor dimensão, e que está a seguir o primeiro, ostenta a cauda para baixo. Ambos têm orelhas bem pronunciadas. O painel 4, no patamar a nordeste do painel 3 , tem inúmeras covinhas de diferentes dimensões (Figura 4).

Bibliografia: Bettencourt, 2014b; dados inéditos.

\section{Nossa Senhora da Assunção 17}

Freguesia: Barbeita

Localização: Latitude: 42.056635; Longitude: -8.406635; Altitude: $223 \mathrm{~m}$.

Historial: Trata-se de um afloramento noticiado por Bettencourt (2014c) e agora alvo de estudo mais detalhado.

Contexto físico e ambiental: numa plataforma a meio da vertente sudeste do Monte de Nossa Senhora da Assunção, um local com excelente visibilidade para o vale onde corre o rio Mouro.

Descrição do afloramento: é elevado do solo, cerca de $43 \mathrm{~cm}$ pelo lado norte e $35 \mathrm{~cm}$ pelo lado sul. $\mathrm{O}$ afloramento, de grão fino, com bastante mica, apresenta uma coloração cinzenta escura em consequência da exposição a um fogo florestal. Além de se estar partido no lado oeste, apresenta depressões retangulares, recentes, realizadas para a inserção de cunhas facilitadoras do corte manual de pedra, bem como alguns sulcos de perfil em $\mathrm{V}$ feitos com pico metálico. $\mathrm{O}$ afloramento apresenta o topo aplanado. Descrição dos motivos: no topo são visíveis motivos atlânticos clássicos, muito erodidos, nomeadamente: um círculo concêntrico com covinha central, atravessado por um sulco e sobreposto por duas covinhas no seu aro exterior, um pequeno círculo concêntrico de duas voltas e, pelo menos, dois círculos simples com covinha central. Ai, existem, também, diversas covinhas. No ligeiro declive, a norte, foi gravado um equídeo sub-naturalista, em movimento (o que é sugerido pela obliquidade dos membros dianteiros). Sobre o dorso tem um sulco disposto na vertical, que poderá simbolizar um cavaleiro sem rédeas ou uma arma fincada. Mede cerca de $26 \mathrm{~cm}$. Dispõe-se na superfície como se dirigisse do fundo do vale (este) para o topo do monte (oeste), como se o seu destino fosse o topo do Monte da Senho- ra da Assunção. Este animal apresenta a particularidade de ter sobre a cabeça um grande círculo, que parece ter sido sobreposto por uma covinha. Para poente desta figura há outro círculo, de contorno algo irregular, também sobreposto por uma covinha. Em posição oposta a este animal, parece existir outro equídeo muito erodido apenas definido pela linha do dorso, parte superior da cabeça e orelhas, cauda (?) e início de um dos membros traseiros. Pela disposição no afloramento dirige-se para o vale, ou seja, para nascente. No declive sul parece existir uma cruz grega (Figura 5).

Bibliografia: Bettencourt, 2014c; dados inéditos.

\section{Nossa Senhora da Assunção 19 \\ Freguesia: Barbeita \\ Historial: inédito \\ Localização: Latitude: 42.056281, Longitude: -8.40 7950; Altitude: $249 \mathrm{~m}$.}

Contexto físico e ambiental: a cerca de $50 \mathrm{~m}$ para sudeste de Nossa Senhora da Assunção 15, a meio da vertente média do Monte de Nossa Senhora da Assunção, com um declive bastante acentuado. De costas para o parque de estacionamento do monte da Senhora da Assunção, a E-SE, existe uma ampla visão para o vale onde corre o rio Mouro. A N-NE situa-se o Monte da Senhora da Assunção.

Descrição do afloramento: trata-se de um grande afloramento dividido por diáclases bastante acentuadas, de grão fino e com alguns filões de quartzito. Em algumas áreas apresenta-se bastante escuro devido a incêndios e com alguns líquenes.

Descrição dos motivos: o afloramento está dividido em dois painéis por uma diáclase. No painel a este surge um cavaleiro montado sobre um equídeo de cerca de $15 \mathrm{~cm}$, muito esquemático, e um círculo. O painel oeste está profusamente gravado com motivos variados. Destaque para uma espiral com covinha no meio, podomorfos descalços na horizontal e na vertical, uma gravura de um objeto com um cabo e dois dentes (fúrcula/gancho de carne do Bronze Final?), uma covinha de onde parte um sulco orientado a norte e duas covinhas unidas por um sulco bem pronunciado (Figura 6).

Bibliografia: inédita.

\section{Baldio da Porqueira}

Freguesia: Longos Vales.

Localização: Latitude: 42.0428; Longitude: -8.40 71; Altitude: $179 \mathrm{~m}$. 
Historial: inédita.

Contexto físico e ambiental: este afloramento situa-se na subida do caminho do Baldio da Porqueira, no lado direito. Tem excelente visibilidade para este onde corre o rio Mouro. A norte avista-se o monte da Senhora da Assunção.

Descrição do afloramento: trata-se de um afloramento bastante sobrelevado do solo, cerca de 2,00 m na parte norte e 1,20 $\mathrm{m}$ a sul. De um granito bastante claro, tem uma forma côncava. Apresenta uma zona bastante escura no centro em parte resultante da acumulação de águas pluviais,

Descrição dos motivos: um equídeo esquemático dirige-se para um grande círculo concêntrico com pelo menos 5 voltas e covinha central que está gravado praticamente no centro do afloramento. Devido à sua forma côncava, o afloramento acumula águas pluviais que devido à gravidade escorrem para o equídeo. É possível distinguir um pequeno sulco no dorso do equídeo com o recurso à luz rasante, no entanto não é possível afirmar tratar-se de um equídeo montado (Figura 7 ).

Bibliografia: inédito.

\section{Coutada das Águas 1}

Freguesia: Longos Vales

Localização: Latitude: 42.051389; Longitude: -8.41 0556; Altitude: $242 \mathrm{~m}$.

Historial: este afloramento foi dado a conhecer por Bettencourt (2014a) tendo agora sido alvo de estudo pormenorizado.

Contexto físico e ambiental: encontra-se a cerca de $300 \mathrm{~m}$ do núcleo de gravuras da Buraca da Moura, num pequeno remate de esporão sobranceiro ao Rego das Cunhas. A nascente, visualiza-se o vale do rio Mouro, enquanto para sul a perspetiva é para o vale do Rego das Cunhas, que vai desaguar no rio Mouro. O local fica num aglomerado de blocos graníticos, de grão médio a fino.

Descrição do afloramento: afloramento gravado, bem destacado do solo, com dois declives medianos, um para nascente e outro para poente que se tornam mais abruptos perto do solo. Encontra-se em razoável estado de conservação, embora apresente alguns líquenes.

Descrição dos motivos: no declive a nascente, foram gravados dois equídeos esquemáticos, um em posição estática e outro dando a sensação de estar em movimento, sugerido pela linha do dorso e pela posição da cabeça e dos membros dianteiros. A fi- gura central do afloramento dirige-se para W-NE e é um pouco maior do que o outro que se encontra na extremidade oeste do painel. Este último dirige-se para E-SE. Ambos provocam a sensação, para quem os olha de frente, que estão a sair do vale e se dirigem para o monte. $\mathrm{O}$ declive a poente exibe um grande circulo concêntrico de quatro voltas com covinha central, um equídeo esquemático, em posição estática, que se dirige para W-NW e um outro, também esquemático, dirigindo-se em sentido contrário (Figura 8).

Bibliografia: Bettencourt, 2014d; dados inéditos.

\section{Teixugos 2}

Freguesia: Longos Vales

Localização: Latitude: 42.056417; Longitude: -8.42 5889; Altitude: $118 \mathrm{~m}$

Historial: noticiada por Bettencourt (2014d).

Contexto físico e ambiental: este afloramento localiza-se no início da vertente, numa zona aplana$\mathrm{da}$, bastante encoberto pela vegetação, o que torna difícil a sua visualização. Está rodeado por campos agrícolas.

Descrição do afloramento: trata-se de um grande afloramento, rente ao solo, com um ligeiro declive de S-SW para N-NE. Mede cerca de 6,30 m no sentido S-SW/N-NE e 2,6o m no sentido W-NW/E-SE. Apresenta algumas diaclases e um grande filão horizontal de quartzito na parte central dividindo a rocha em dois painéis. Na parte inferior são também visíveis mais alguns filões de quartzito. O afloramento está um pouco danificado em consequência de incêndios florestais. A zona mais a N-NE encontra-se bastante escurecida.

Descrição dos motivos: o afloramento é profusamente gravado. Na parte superior do painel é visível um circulo concêntrico de 3 voltas, e um motivo circular. Um pouco mais abaixo encontramos uma gravura de forma sub retangular.

Mais abaixo, e muito perto do filão de quartzito, são visíveis pelo menos 21 covinhas, sendo que duas delas estão unidas por um sulco, e quatro estão circundadas por uma forma mais ou menos ovalada.

Logo após a filão, e no que foi considerado o segundo painel, encontram-se mais algumas covinhas, pelo menos 5, ao lado de um círculo concêntrico de 4 voltas e de menor dimensão do que o do painel superior. Ao lado inicia-se um sulco de forma irregular que desce o afloramento, medindo pouco mais de um metro, com uma gravura sub rectangular ados- 
sada. Ao lado, e no alinhamento do rectângulo, surgem 3 figuras de forma mais ou menos circular e de difícil interpretação.

Mais abaixo, surge um equídeo sub naturalista, em posição estática, voltado para N-NW e para um conjunto de outros 2 equídeos que o enfrentam. Um deles, esquemático, é montado por um ginete que surge de braços abertos podendo estar a segurar alguma coisa. Num outro equídeo, sub naturalista, também montando, o ginete parece ostentar um bastão. É visível ainda mais um zoomorfo, embora pareça que não tenha sido terminado (Figura 9).

Bibliografia: Bettencourt, 2014e; dados inéditos.

\section{Teixugos 3}

Freguesia: Longos Vales

Localização: Latitude: 42,0568N; Longitude: $-8,42$ 43W; Altitude: $118 \mathrm{~m}$

Historial: inédito

Contexto físico e ambiental: situa-se a escassos metros de habitações num declive pouco pronunciado orientado de SW para NE. Apresenta visibilidade para o vale a E-SE e para o Monte da Senhora da Assunção a Este.

Descrição do afloramento: trata-se de um grande afloramento com 2,40 $\mathrm{m}$ (sentido SW para NE) por 1,30 (sentido SE para NW), rasante ao solo, formando um declive com leve inclinação. Com uma forma mais ou menos sub retangular, de granito fino e coloração cinzenta escura, está naturalmente dividido em 3 painéis através de diáclases bem pronunciadas e largas.

Descrição dos motivos: os equídeos surgem no painel 1 (que se encontra mais a NE). Aí, evidencia-se um círculo concêntrico com, pelo menos, 4 voltas. No seu centro tem 3 covinhas, um pouco mais abaixo, o equídeo sub naturalista, e bem definido, orientado de W-NW para E-SE (Figura 10).

Bibliografia: dados inéditos.

\section{Chã/Chão da Sobreira 2}

Freguesia: Podame.

Localização: Latitude: 42.04608o; Longitude: -8.35 8163; Altitude: $370 \mathrm{~m}$

Historial: foi descoberto e estudado, em 1986, por José Augusto Maia Marques, que fez o seu decalque em polivinilo após a aplicação do método biocromático.

Contexto físico e ambiental: ampla visibilidade a norte para o vale. Em plano de fundo encontra-se o Castro da Senhora da Graça. Visibilidade fechada para sul, este e oeste.

Descrição do afloramento gravado: trata-se de um afloramento granítico de grão médio, algo destacado do solo, aplanado na parte superior, com um declive para sul. Encontra-se escondido por densa vegetação, um pouco erodido e coberto com líquenes e musgos. Descrição dos motivos: apresenta três painéis gravados, separados por algumas diáclases (Fig. 10). No painel norte, destaca-se uma covinha central associada a um sulco, rodeada por dois semicírculos, várias covinhas isoladas e sulcos que formam duas composições de difícil classificação. No painel encontra-se uma espiral de duas voltas e várias covinhas, algumas associadas a sulcos.

No painel sul, encontram-se os motivos mais importantes para este estudo. Trata-se uma cena de equitação com dois equídeos esquemáticos montados, de aproximadamente $20 \mathrm{~cm}$ cada um, dirigindo-se de nascente para poente. O ginete do equídeo da frente, com uma dimensão ligeiramente maior, parece ser portador de um toucado, tem os braços abertos e ostenta um objeto de morfologia circular preso à cintura, enquanto o equídeo de trás, com um cavaleiro muito estilizado, parece percorrer um caminho representado por um sulco, segundo interpretação de Bettencourt (2014).

Todas as figuras foram gravadas por percussão seguida de abrasão (Figura 11).

Bibliografia: Marques, 1986; Bettencourt, $2014 f$.

\section{DISCUSSÃO DE RESULTADOS E INTERPRETAÇÕES}

Os equídeos aqui estudados integram 10 afloramentos (Baldio da Porqueira 1, Buraca da Moura 5, Chã da Sobreira 2, Coutada das Águas 1, Coutada das Águas 3, Nossa Senhora da Assunção 15, 17 e 19, Teixugos 2 e 3), inscritos em 6 núcleos de arte rupestre (Tab. 1).

Todos eles se localizam no curso inferior do rio Mouro, em ambas as suas margens. São frequentes em pequenos patamares de vertentes médias de montes, entre os 100 e os 300 metros de altitude e em áreas com domínio para vales subsidiários da bacia do Mouro, com exceção de Teixugos, que se situa um pouco mais afastado e num local com pouca visibilidade, talvez devido à densa cobertura arbórea. (Figura 1). (Tabela 1) 
Não existe homogeneidade na escolha da superfície gravada. Há equídeos em afloramentos rasantes ao solo e bastante horizontalizados, como é o caso da Buraca da Moura 5, Teixugos 2 e 3 e Gasgaia, mas também elevados e em painéis com declive. Encontram-se neste caso os do Baldio da Porqueira 1 e de Nossa Senhora da Assunção 15, 17 e 19.

Em 7 casos os equídeos coexistem na mesma superfície com motivos atlânticos clássicos, embora, em 3 casos sem articulação direta com eles, dando a impressão de terem sido adicionados posteriormente. É o caso de Nossa Senhora da Assunção 15, 17, Chã da Sobreira 2 e, parcialmente, da Coutada das Águas 1, onde os motivos atlânticos se encontram no topo do afloramento e os equídeos em declives ou posições muito periféricas. Já na Gasgaia, Teixugos 2, do Baldio da Porqueira 1 e no declive nascente da Coutada das Águas 2, apesar dos equídeos estarem em posição periférica, parecem ter sido colocados de forma a dialogar com círculos concêntricos. De salientar que em termos técnicos estes quadrúpedes são sempre pouco profundos e com sulcos ligeiramente menos largos que os das composições circulares, o que acentua a "impressão" da sua gravação num momento distinto. Há também três casos em que os equídeos não ocorrem com motivos clássicos de arte atlântica, parecendo formar composições únicas (Buraca da Moura 5, Nossa Senhora da Assunção 15 e Chã da Sobreira 2). Tal parece estar de acordo com as hipóteses de que a sua gravação seria posterior à arte atlântica clássica defendidas para o Noroeste por Santos-Estévez (2008, 2012), com base na premissa de a equitação não existiu até aos inícios do $1^{\circ}$ milénio a.C. (séc. IX/VIII a.C.) e por Bettencourt (2019a) a propósito dos equídeos sub-naturalistas associados a círculos segmentados que a autora considera da Idade do Bronze, por paralelos com objetos desse período com esse símbolo. Se consideramos que a arte atlântica clássica se inicia no Neolítico e perdura pelo Calcolítico (Alves, 2003, 2009, 2017; Bettencourt, 2009, 2013, 2017a, 2017b; Cardoso, 2015), também é possível admitir que os equídeos no NW da Península Ibérica possam ter sido gravados entre os finais do $3^{\circ}$ e os inícios do $2^{\circ}$ milénio a.C., ou seja, no Bronze Inicial, baseado na hipótese de o cavalo ter sido domesticado nesse período (Fábregas Valcarce, Peña Santos, Rodríguez Rellán, 2011, p. 38).

Em termos de tipos de equídeos sem cavaleiros há os que se gravaram de modo muito esquemático, em
5 afloramentos (Nossa Senhora da Assunção 15 e 19, Coutada das Águas 1 e 3 e Chã da Sobreira 2) e os com mais pormenores, sub naturalistas, onde o corpo e a cabeça são definidos por dois sulcos, em 3 afloramentos (Buraca da Moura 5, Nossa Senhora da Assunção 17, Teixugos 2). É de referir que no afloramento dos Teixugos 2, um dos equídeos é esquemático e 2 são sub-naturalistas. De uma forma geral todos apresentam orelhas bem pronunciadas, o que indicia que poderão representar zebros, um equídeo selvagem que existiu até ao séc. XV (Terrón Albarrán, 1983).

Quer os esquemáticos quer os sub-naturalistas gravaram-se quase sempre de forma estática embora, nalguns casos, o movimento seja indiciado pela inclinações dos membros.

Em termos de composição há equídeos isolados (Gasgaia), em grupos de dois (Nossa Senhora da Assunção 15, 17, 19 Coutada das Águas 1); em manadas de 3 animais (Teixugos 3 ) e de 4 animais (Buraca da Moura 5).

No caso dos equídeos em manada não parece haver grande distinção entre as dimensões dos equídeos esquemáticos, como também não surge nenhum equídeo com gravação especifica de género. Serão todos de fêmeas e crias?

Os equídeos com cavaleiros ocorrem, essencialmente, no grupo dos esquemáticos, em 4 casos (Baldios da Porqueira 1, Nossa Senhora da Assunção 19, Teixugos 2 e Chã da Sobreira 2). Em dois casos ocorrem em cavalos sub-naturalistas (Teixugos 2) em associação com outros não montados. $\mathrm{O}$ caso de Nossa Senhora da Assunção 17 oferece dúvidas sobre ser montado ou ter uma arma fincada.

Já na Assunção 19, o cavaleiro surge de braços abertos, tal como no Teixugos 2, embora este pareça segurar um bastão. Na Chã da Sobreira 2, um dos cavaleiros parece ser portador de um toucado, tem os braços abertos e ostenta um objeto de morfologia circular preso à cintura (um escudo?).

Em termos de equídeos em geral há a destacar que no caso de Nossa Senhora da Assunção 17, estes parecem ser guiados por círculos simples sobre a cabeça. Na Buraca da Moura 5 o último equídeo da manada parece puxar uma figura subcircular. Estaremos face a representações de cavalos solares? E no caso em que parecem dialogar com círculos concêntricos típicos da arte atlântica clássica? Que mensagem quererão transmitir? Este é um trabalho a desenvolver futuramente, assim como a tentativa de interpretação de outras cenas equestres aqui representadas. 


\section{AGRADECIMENTOS}

Os autores expressam um profundo agradecimento ao Sr. José Alvarez Alonso, que com a sua grande disponibilidade e simpatia, nos acompanhou ao campo mostrando os sítios inéditos referidos neste trabalho.

\section{BIBLIOGRAFIA}

ALVES, Lara B. (2009) - O sentido dos signos. Reflexões e perspectivas para o estudo da arte rupestre do pós-glaciar no norte de Portugal. In BALBíN BEHRMANN, Rodrigo , ed. - Actas Arte Prehistórico al aire libre en el Sur de Europa. Junta de Castilla y Léon: Consejaría de Cultura y Turismo, pp. 381-413.

ALVES, Lara B. (2014) - Intermitências: a arte e a Idade do Bronze no ocidente peninsular. In LOPES, Susana, ed. - A Idade do Bronze em Portugal: os dados e os problemas. Antorpe, série monográfica nํํ. Tomar: Instituto Politécnico de Tomar, pp. 15-51.

ALVES, Lara B. e REIS, Mário (2017) - Tattooed Landscapes. A reassessment of Atlantic Art distribution, research methods and chronology in the light of the discovery of a major rock art assemblage at Monte Faro (Valença, Portugal). Zephyrus Revista de Prehistoria y Arqueología, LXXX julio-diciembre 2017, Salamanca. Ediciones Universidad Salamanca, pp. 49-67. DOI: http://dx.doi.org/10.14201/ zephyrus2017804967.

BETTENCOURT, Ana M. S. (2014a) - Coutada das Águas 1, In Corpus Virtual de Arte Rupestre do Noroeste de Portugal - CVARN.

BETTENCOURT, Ana M. S. (2014b) - Nossa Senhora da Assunção 15, In Corpus Virtual de Arte Rupestre do Noroeste de Portugal-CVARN. (www.cvarn.org).

BETTENCOURT, Ana M. S. (2014c) - Nossa Senhora da Assunção 17, In Corpus Virtual de Arte Rupestre do Noroeste de Portugal-CVARN. (www.cvarn.org).

BETTENCOURT, Ana M. S. (2014d) - Buraca da Moura I, In Corpus Virtual de Arte Rupestre do Noroeste de Portugal - CVARN. (www.cvarn.org).

BETTENCOURT, Ana M. S. (2014e) - Teixugos 2, In Corpus Virtual de Arte Rupestre do Noroeste de Portugal - CVARN. (www.cvarn.org).

BETTENCOURT, Ana M. S. (2014f) - Chã da Sobreira 1, $2 e$ 3, In Corpus Virtual de Arte Rupestre do Noroeste de Portugal-CVARN. (www.cvarn.org).

BETTENCOURT, Ana M. S. (2017a) - Gravuras rupestres do Noroeste para além das artes atlânticas e esquemática. In ARNAUD, José M. e MARTINS, Andrea, eds - Arqueologia em Portugal. Estado da Questâo. Associação dos Arqueólogos Portugueses, Lisboa: AAP, pp. 1053-1067.
BETTENCOURT, Ana M. S.; SAMPAIO, Hugo A.; SANTOS -ESTÉVEZ, Manuel; CARDOSO, Daniela (2017b) - Prehistoric Rock Art and Landscape: The outcrops and its forms were certainly not simple carving surfaces. In MARTINS, R. N. e RIBEIRO, C., eds. - I International Seminar on Art and Landscape. Guimarães, Laboratório da Paisagem, pp. 137-153.

BETTENCOURT, Ana M. S. (2019a) - Equídeos nos Montes do Noroeste Português. Narrativas Míticas Gravadas nas Rochas. In PEREIRA, Andreia, ed. - O Garrano: contributos da investigação histórico-arqueológica, antropológica e equestre para a sua valorização. Viana do Castelo: Câmara Municipal, pp. 135-148.

BETTENCOURT, Ana M. S. (2019b) - Artes Rupestres do Alto Minho. In CAMPELO, Álvaro, ed. - Património artístico e cultural do Alto Minho. Uma viagem no tempo. Viana do Castelo: Comunidade Intermunicipal do Alto Minho (no prelo).

BETTENCOURT, Ana M. S. e ABAD-VIDAL, E. (2014) Corpus Virtual de Arte Rupestre do Noroeste de Portugal - CVARN (www.cvarn.org)

BRADLEY, R. (200o) - An Archaeology of Natural Places. London: Routledge, https://doi.org/10.4324/978020363 O228

CARDOSO, Daneila (2015) - A Arte Atlântica do Monte de S. Romão (Guimarães) no contexto da arte rupestre pós-paleolítica da bacia do Ave - Noroeste português. Tese de Doutoramento, Universidade do Vila Real, Vila Real, Portugal.

FÁBREGAS VALCARCE, R.; PEÑA SANTOS, A.; RODRÍGEZ RELLÁN, C. (2011) - Río de Angueira 2 (Teo, A Coruña). Un conxunto excepcional de escenas de monta, Gallaecia, 30, 29-51.

MARQUES, José A. M. (1986) - As gravuras da Chã da Sobreira e a arte rupestre do concelho de Monção, Revista de Ciências Históricas, 1, pp. 11-29.

MARTÍNEZ SOTO, Eloy; VERDE ANDRÉS, Cándido; ALVAREZ, Xosé; CENTELLES GARCÍA, Bruno; MANSO DE LA TORRE, Xilberte; VILAR PEDREIRA, Xosé Lois; LEDO BERNÁRDEZ, Manuel (2017) - Proxecto Equus: un novo paradigma nas escenas de caza da arte rupestre galega e do norte de Portugal. Revista de Estudos Miñoráns, 16/17, pp. $23-75$.

RIBEIRO, M. Luisa; MOREIRA, Armando (1986) - Carta Geológica de Portugal na escala 1/500oo - 1B. Notícia explicativa da folha 1-B - Monção. Serviços Geológicos de Portugal. Lisboa.

SAMPAIO, Hugo A. S., BETTENCOURT, Ana M. S.; SANTOS-ESTÉVEZ, Manuel; MOREIRA, José; CACHETAS, Henrique; BARBOSA, Aléssia, (2018) - Preservando a Memória das Pedras. Vista, Revista de Cultura Visual, 2, pp. 148-163.

SANTOS-ESTÉVEZ, Manuel (2008) - A new proposal for the chronology of Atlantic rock art in Galicia (NW Iberian 
Peninsula). In NASH, George; CHILDREN, George eds. The Archaeology of Semiotics and the Social Order of Thinks (140-152). Oxford: Bar International Series 1833.

SANTOS-ESTÉVEZ, Manuel. (2012) - Da "Arte Atlântica" no contexto europeu: conceitos, problemáticas e perspectivas - unha visión diacrónica da Arte Atlântica dentro dun novo marco cronolóxico. In SANCHES, Maria de Jesus ed. - Artes Rupestres da Pré-História e da Proto-História: Paradigmas e Metodologias de Registo. $1^{\circ}$ Mesa Redonda. Trabalhos de Arqueologia 54, Lisboa: MC, pp. 226-235.

SANTOS-ESTÉVEZ, Manuel (2014) - Curros na Idade do Ferro? Unha proposta etnoarqueolóxica. Fol de Veleno. Anuario de Antropoloxía e Historia de Galiza, 4, pp.135-146.
TERRÓN ALBARRÁN, M. (1983) - Los asnos salvajes, cebros o encebros en la España medieval y Extremadura. Aspectos histórico-geográficos y caza. In Memorias de la Real. Academia de Extremadura de las Letras y las Artes, I, pp. 413-474.

TILLEY, C. (2002) - Metaphor, materiality and interpretation. In BUCHLI, V. ed. - The Material Culture Reader. Oxford: Berg. pp. 23-26.

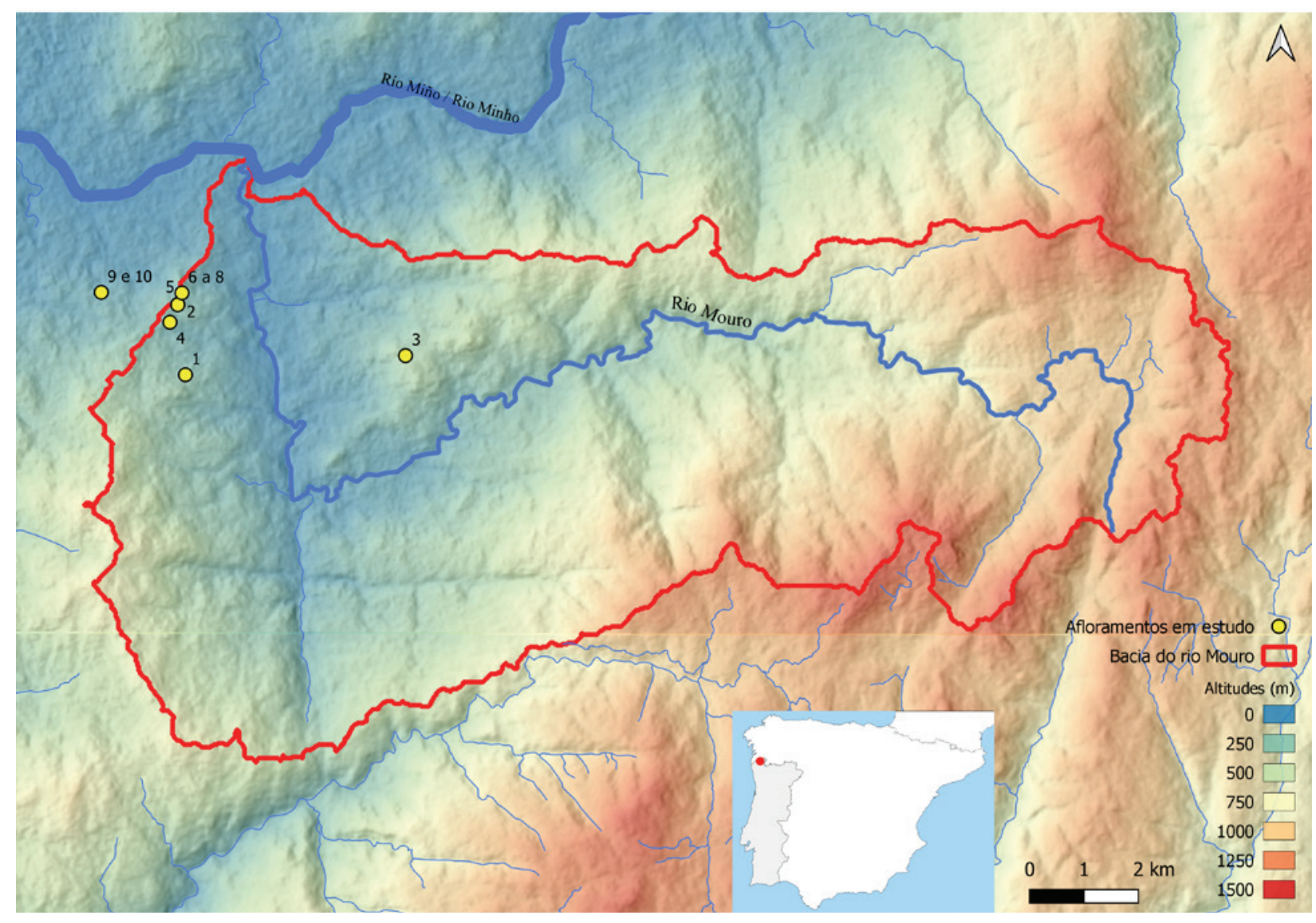

Figura 1 - Localização da Bacia do rio Mouroe das gravuras rupestres citadas no texto. 


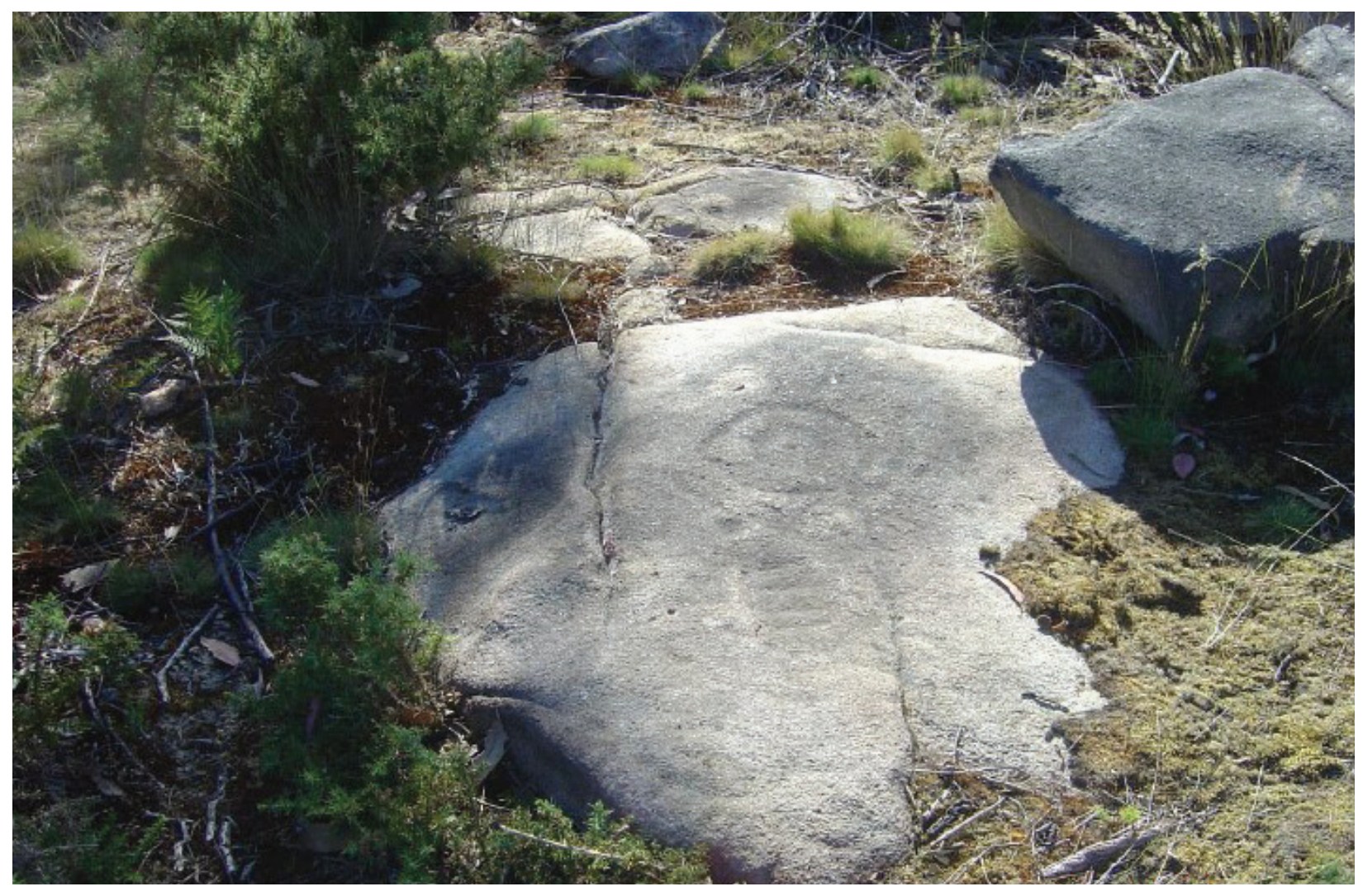

Figura 2 - Gasgaia. Vista geral do afloramento (seg. Bettencourt, 2014d).
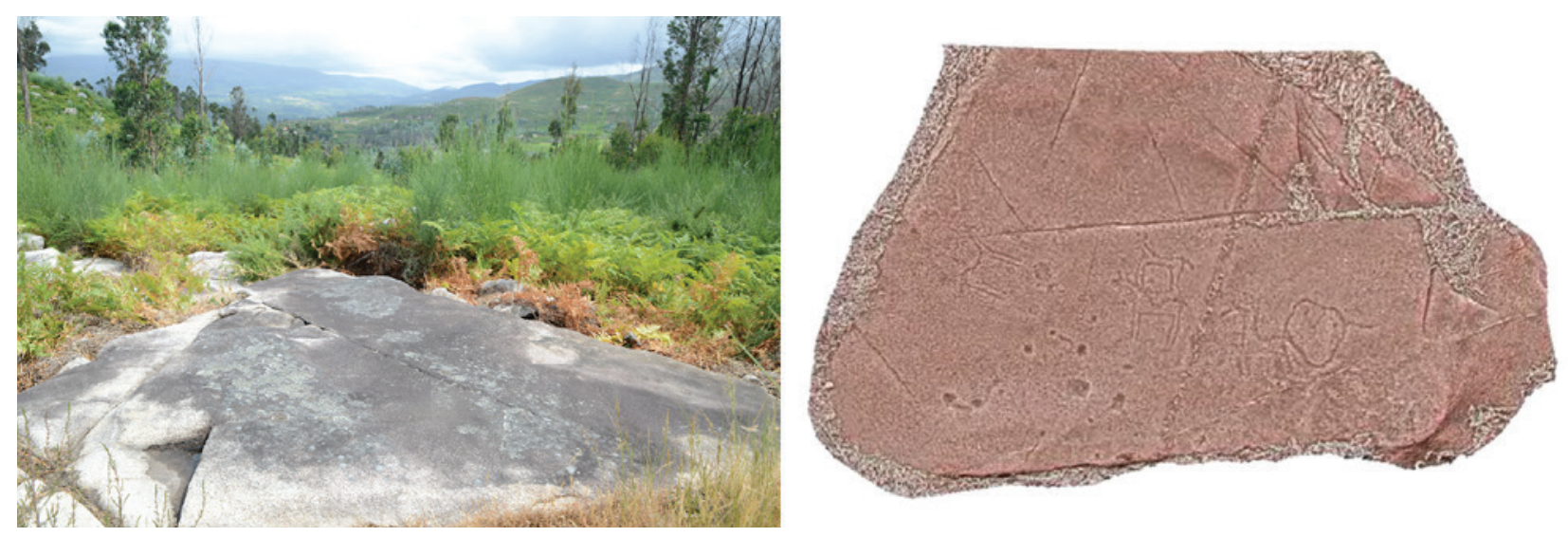

Figura 3 - À esquerda uma vista geral para o vale do rio Mouro a partir da Buraca da Moura 5. À direita fotogrametria da Buraca da Moura 5 (seg. MARTÍNEZ-Soto, et alli (2017). 

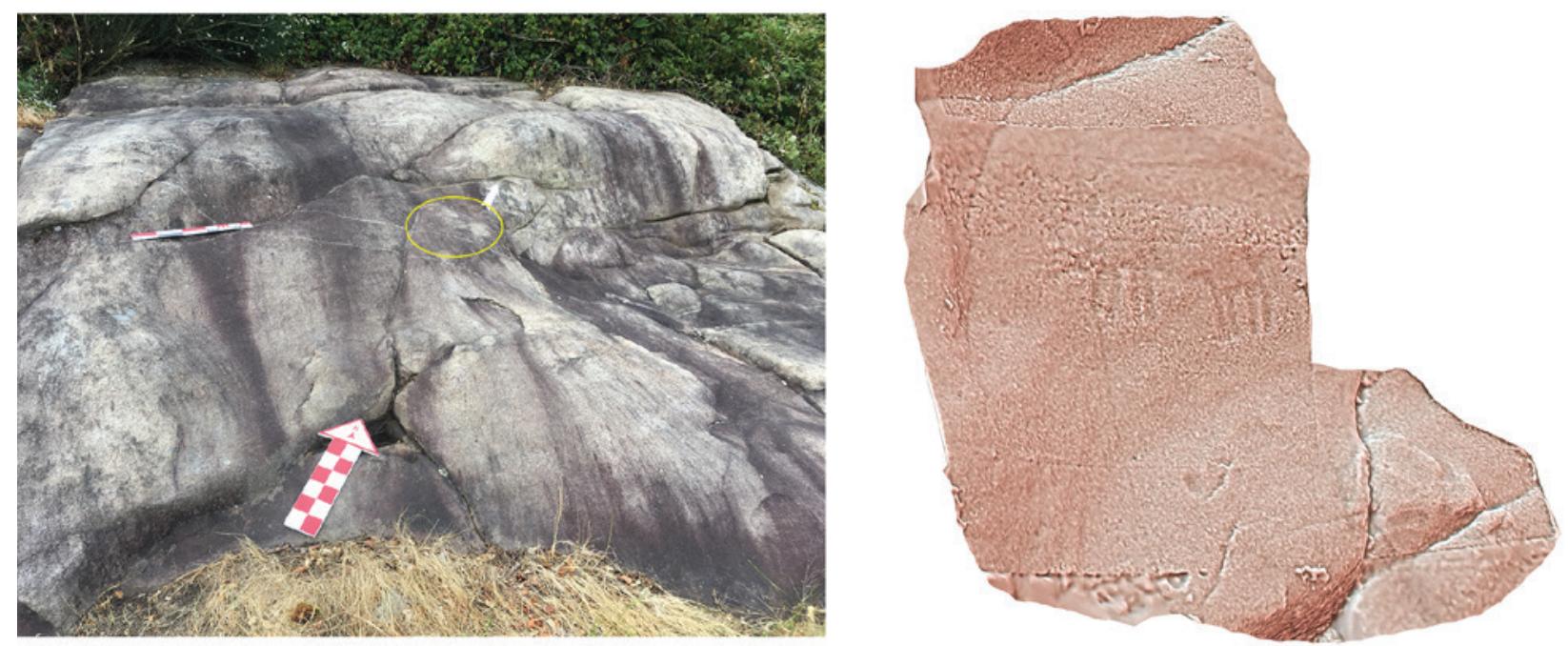

Figura 4 - À esquerda: Vista geral de Nossa Senhora da Assunção 15 com localização do painel com equídeos; à direita: fotogrametria dos equídeos gravados.
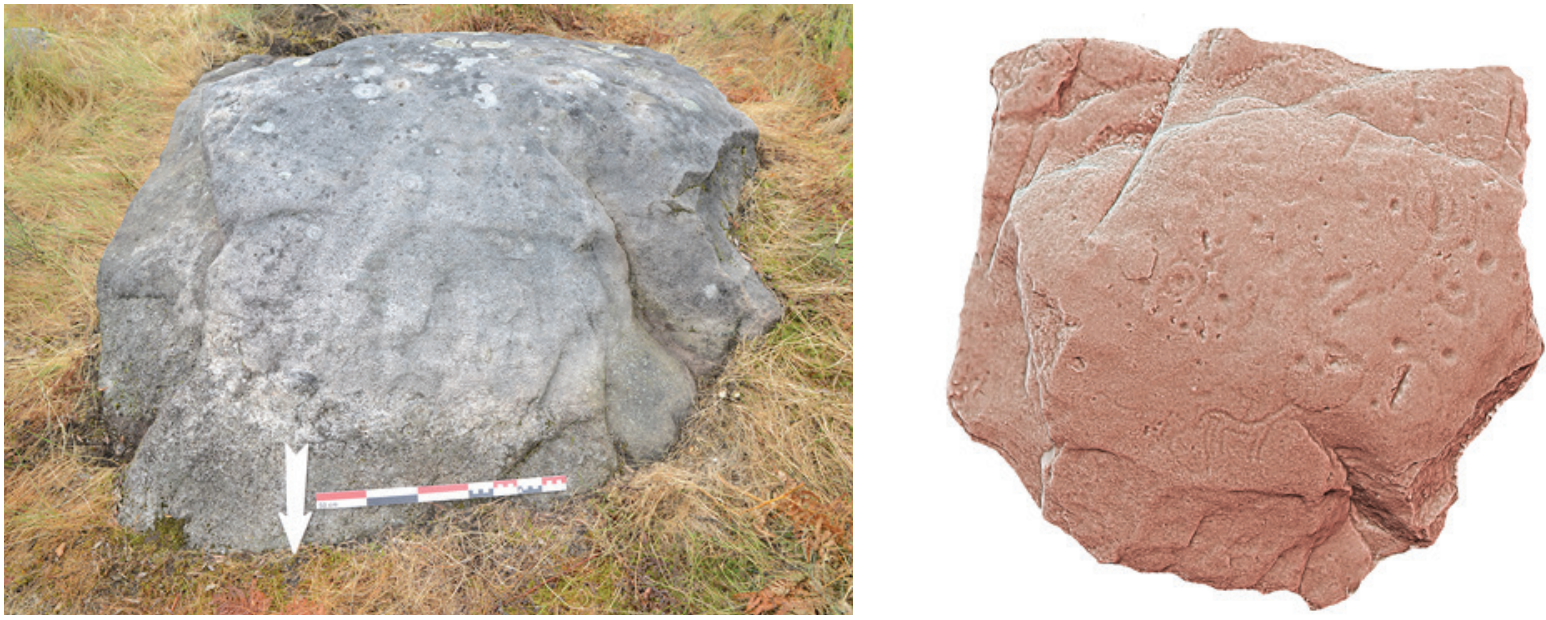

Figura 5 - Fotografia e levantamento fotogramétrico de Nossa Senhora da Assunção 17.

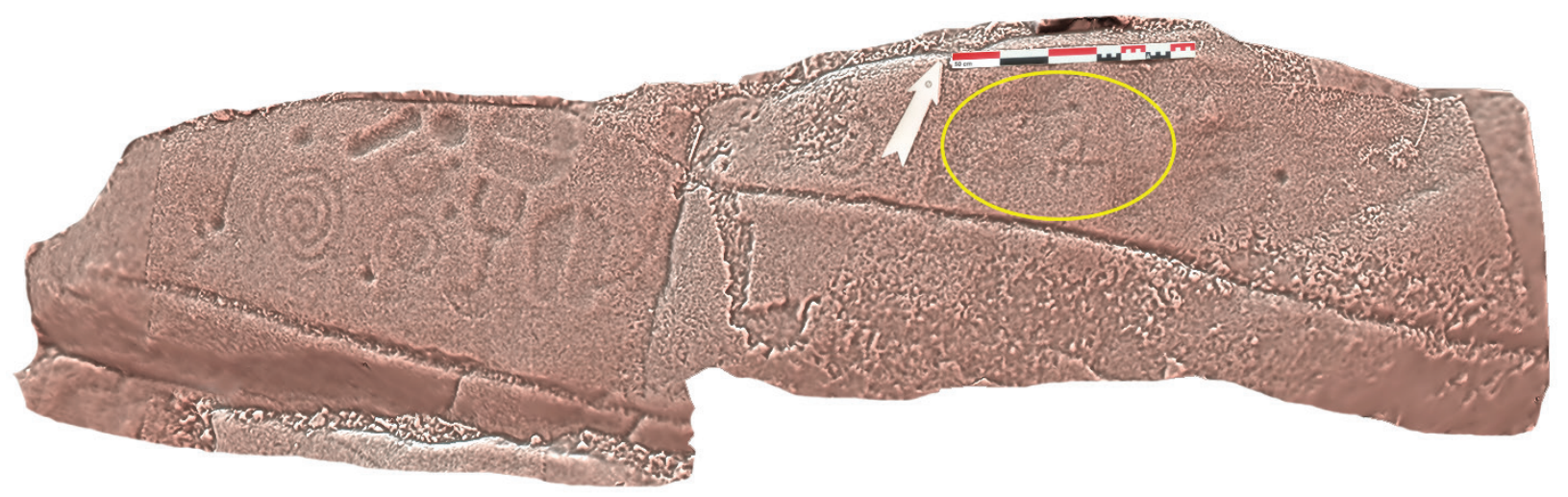

Figura 6 - Levantamento fotogramétrico do afloramento da Nossa Senhora da Assunção 19. 

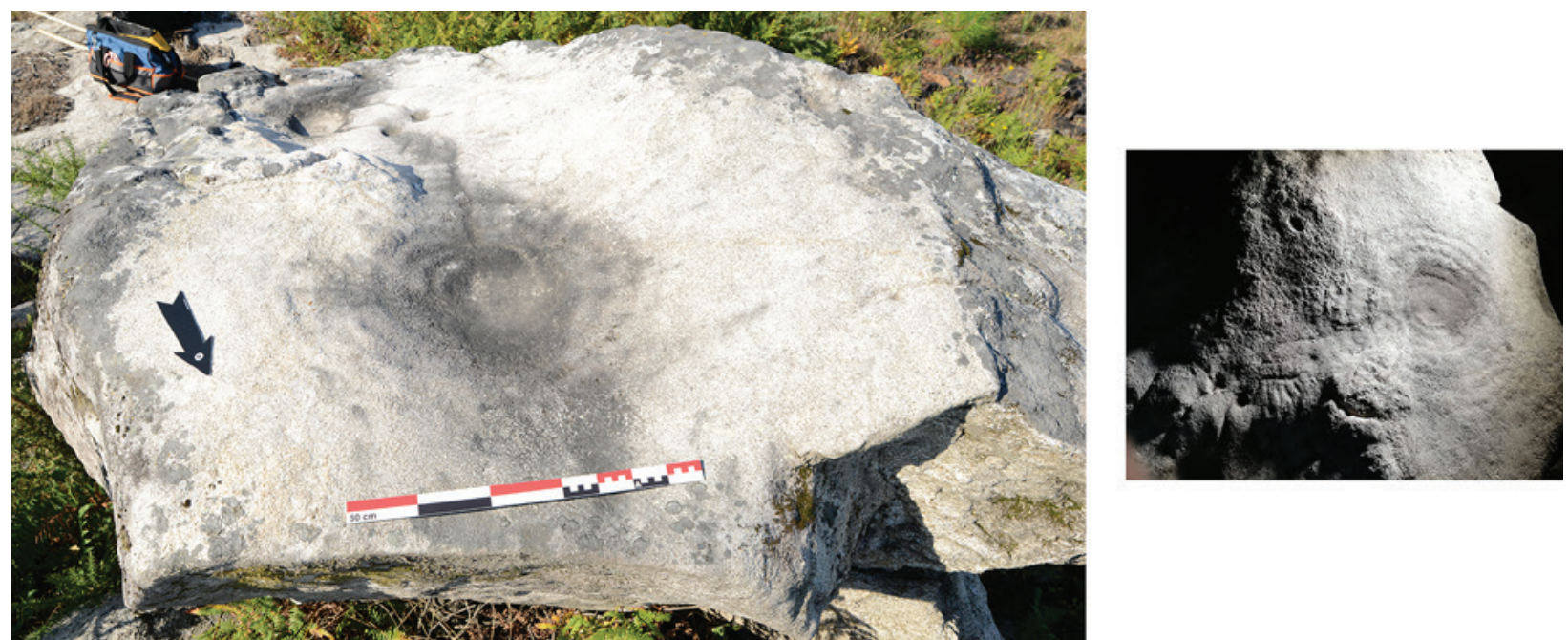

Figura 7 - Afloramento do Baldio da Porqueira. à direita com luz rasante (foto: José Alvarez Alonso).
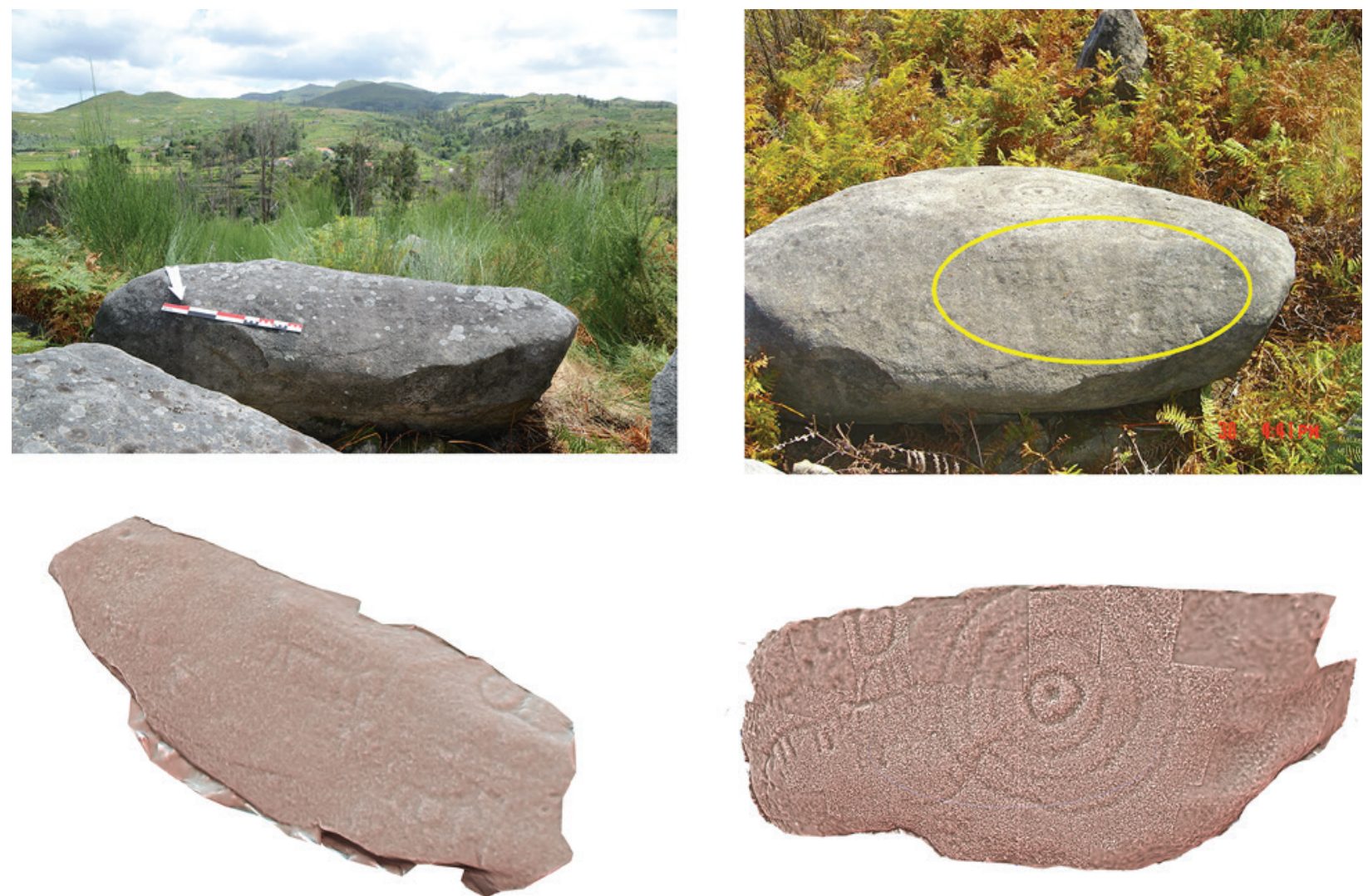

Figura 8 - Em cima, enquadramento paisagístico da Coutada das Águas 1 (à esquerda), e pormenor da vista do declive a nascente (à direita - Imagem: Bettencourt, Ana M. S. e Abad-Vidal, E. (2014d). Em baixo, levantamento fotogramétrico do declive a nascente (à esquerda) e poente (à direita). 


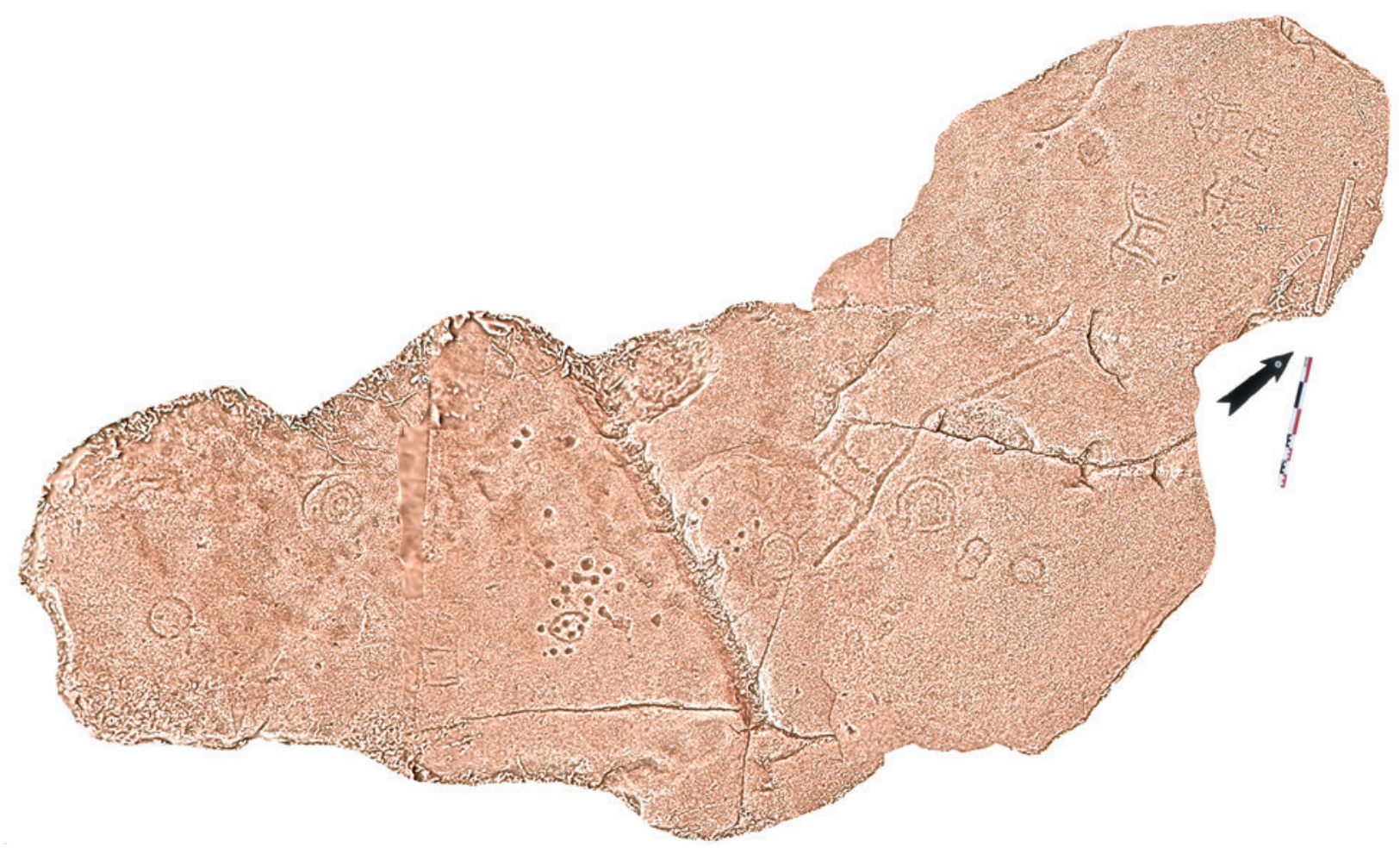

Figura 9- Fotogrametria do afloramento Teixugos 2.
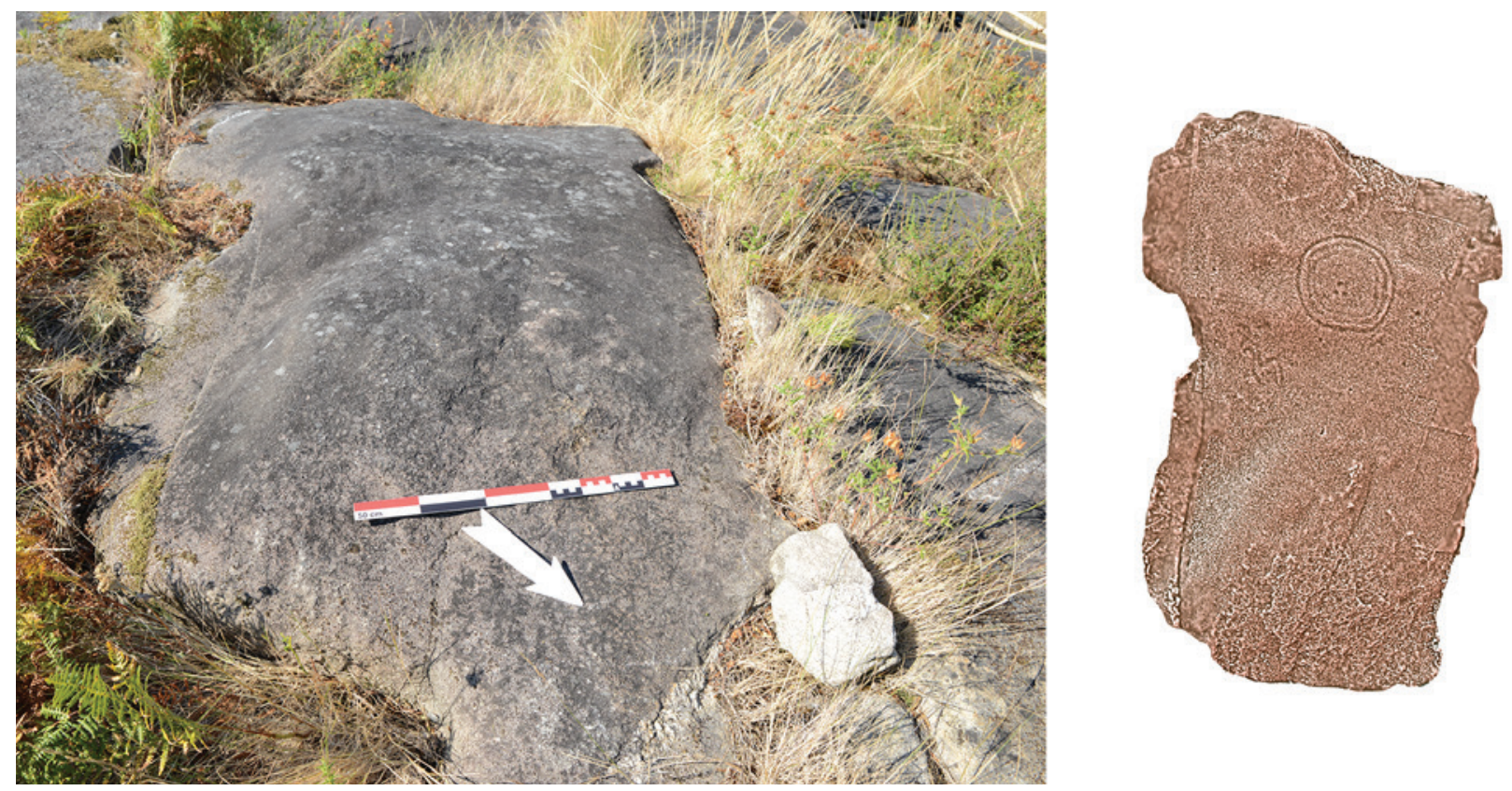

Figura 10 - Teixugos 3. Vista geral do painel 1 (à esquerda) e levantamento fotogramétrico (à direita). 

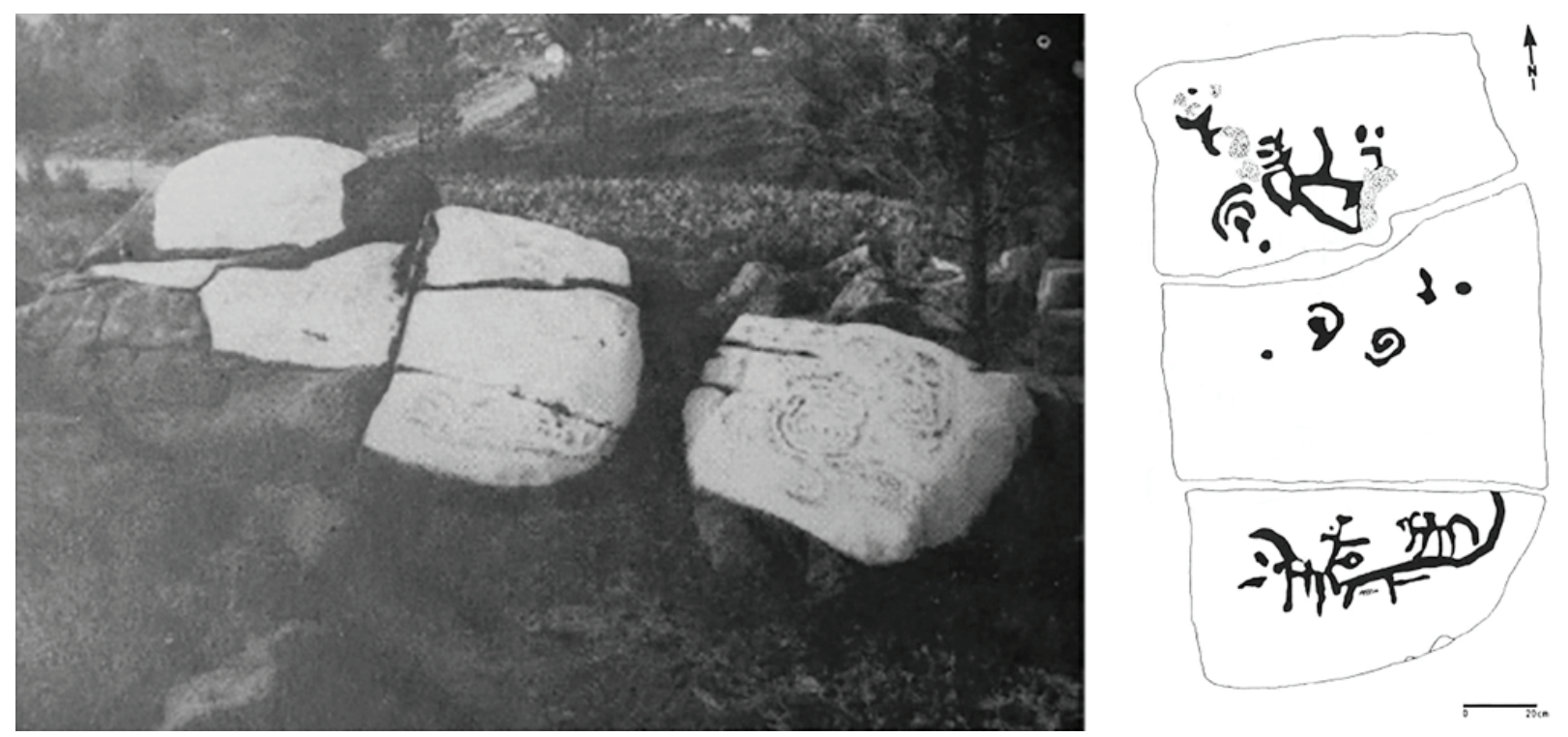

Figura 11 - À esquerda: decalque da Chã da Sobreira 1, 2 e 3 (seg. Marques, 1986, p. 19) e à direita: fotografia do sítio com bicromático (seg. Marques, 1986, p. 26).

\begin{tabular}{|l|l|l|l|}
\hline \multicolumn{1}{|c|}{ Sítio } & Freguesia & Concelho & \multicolumn{1}{|c|}{ Referência bibliográfica } \\
\hline Baldio da Porqueira 1 & Longos Vales & Monção & Inédito \\
\hline Buraca da Moura 5 & Barbeita & Monção & Martínez-Soto, et alii 2017 \\
\hline Chã da Sobreira 2 & Podame & Monção & Marques, 1986; Bettencourt, 2014f \\
\hline Coutada das Águas 1 & Longos Vales & Monção & Bettencourt, 2014a \\
\hline Gasgaia & Barbeita & Monção & Bettencourt, 2014d \\
\hline Nossa Senhora da Assunção 15 & Barbeita & Monção & Bettencourt, 2014b \\
\hline Nossa Senhora da Assunção 17 & Barbeita & Monção & Bettencourt, 2014c \\
\hline Nossa Senhora da Assunção 19 & Barbeita & Monçã̃o & Inédito \\
\hline Teixugos 2 & Longos Vales & Monção & Bettencourt, 2014e \\
\hline Teixugos 3 & Longos Vales & Monção & Inédito \\
\hline
\end{tabular}

Tabela 1 - Sítios arqueológicos com equídeos da bacia do rio Mouro. 



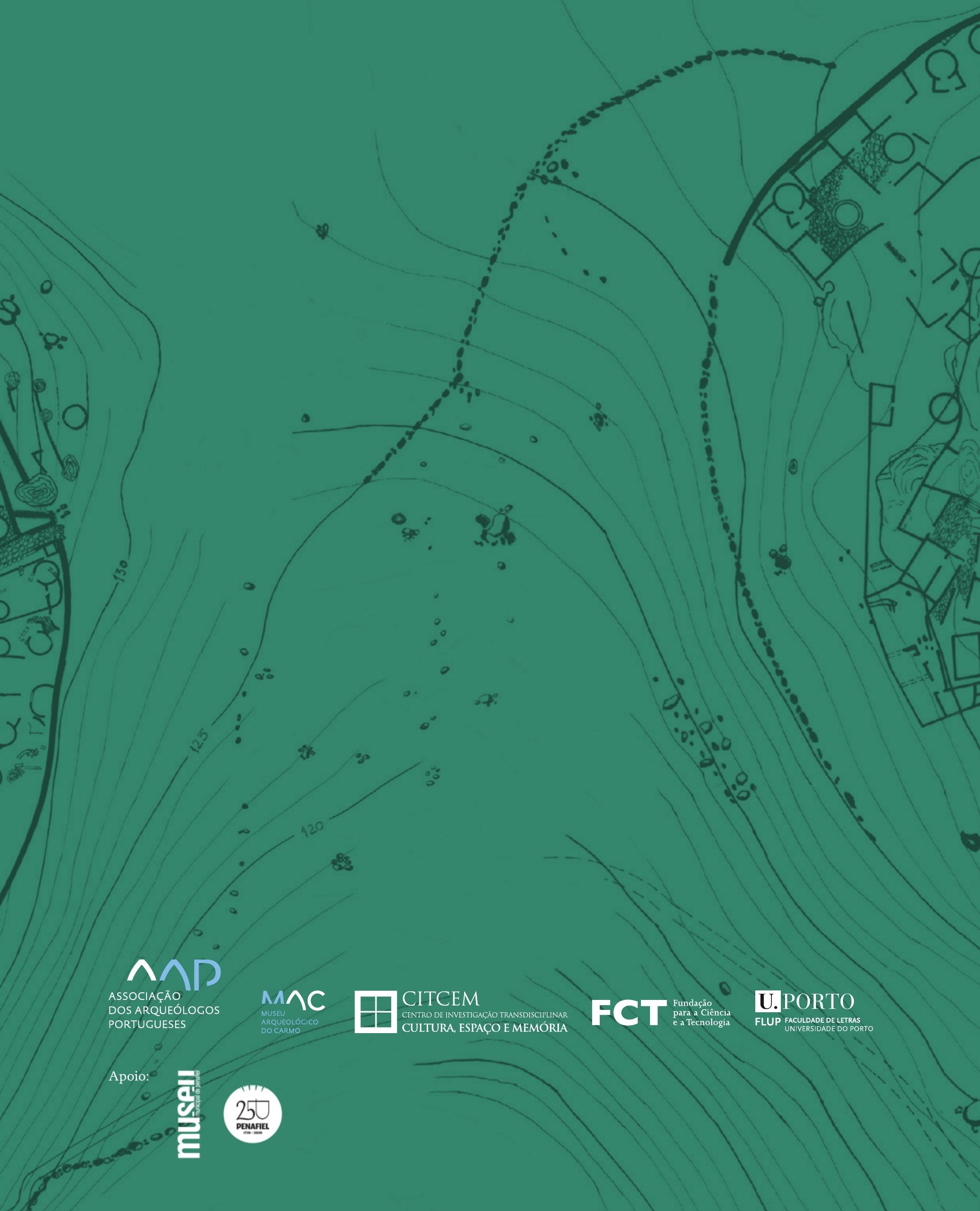

